\title{
Sources of laminated sediments in the northeastern Arabian Sea off Pakistan and implications for sediment transport mechanisms during the late Holocene
}

\author{
Sven Forke, 1,2 Tim Rixen, 1,3 Nicole Burdanowitz, ${ }^{3}$ \\ Andreas Lückge, ${ }^{4}$ Venkitasubramani Ramaswamy, ${ }^{5}$ Philipp Munz, ${ }^{6}$ \\ Dorothee Wilhelms-Dick, ${ }^{7}$ Christoph Vogt, ${ }^{2}$ Sabine Kasten ${ }^{2,7,8}$ and \\ Birgit Gaye 3
}

\begin{abstract}
Laminated sediments of the continental slope off the Makran coast in the northern Arabian Sea are well-known climate archives and record productivity, as well as supply of material from land. Here, we studied sediment core $275 \mathrm{KL}$ off Pakistan in concert with sediment trap, dust and river samples in order to characterize and quantify land-derived material deposited in varves and event layers. We analysed grain sizes, mineral assemblages, bulk components and stable isotopes $\left(\delta^{13} \mathrm{C}, \delta^{18} \mathrm{O}\right)$ of carbonates. In winter, enhanced river discharge is the main source of lithogenic matter contributing the major amounts to the total annual sedimentation of the northern Arabian Sea. During the late summer season, lithogenic matter accumulation is slightly enhanced, probably carried along with the south-eastward blowing Levar winds from the Balochistan and the Sistan Basins and the summer monsoon discharge maximum of perennial streams. $\mathrm{C} / \mathrm{N}$ ratios and stable carbon and oxygen isotopes could not be used to distinguish between organic matter produced on land and in the ocean, whereas stable carbon and oxygen isotope ratios of carbonates suggest that sedimentation of event layers is dominated by direct inputs from land. Catastrophic denudation and storm events occur on average once every 50 years and lead to sedimentation rates that exceed the mean annual sedimentations of $983 \mathrm{~g} \mathrm{~m}^{-2} \mathrm{yr}^{-1}$ by 6 to 10 times. Nevertheless, due to their rare occurrence, they contributed only $7 \%$ to the total sedimentation during the last ca. 5000 years. End-member modelling of grain sizes in accordance with lithogenic matter accumulation rates and event layer frequencies showed that arid conditions prevailed between 4000 and 5000 a BP while more humid conditions commenced around 2000 ka BP in accordance with the Pacific ENSO record.
\end{abstract}

\section{Keywords}

Arabian Sea, ENSO, erosion, grain size, Holocene climate, laminated sediments, lithogenic matter, western disturbances

Received 19 November 2015; revised manuscript accepted 30 August 2018

\section{Introduction}

The Indian summer monsoon is the main driver of climate variability feeding the perennial streams of southern Asia and despite strong efforts still difficult to predict (Gadgil, 2003; Jayaraman, 2002). A source of precipitation in central southwest Asia are the so-called western disturbances (WD) entailing episodic winter rains (Syed et al., 2010) and strongly affecting winter discharge of the Makran rivers (Lückge et al., 2001, 2002). Utilizing the excellent highly resolved marine sedimentary archives of the northern Arabian Sea helps to better understand the monsoon system and WD intensities. Northern Arabian Sea sediments are well known for their continuous seasonal varve-like lamination that is characterized by an alternation of dark and bright laminae with the potential of seasonally resolved paleo-reconstructions (Lückge et al., 2002; Von Rad et al., 2002b). Until now, these archives have been used to reconstruct sea surface temperatures and salinities (Böll et al., 2014; Doose-Rolinski et al., 2001; Munz et al., 2015), marine productivity (Böll et al., 2014; Von Rad et al., 1999a, 2002b), as well as inputs of pollen (Ivory and Lézine, 2009) and lithogenic matter from land (Lückge et al., 2001, 2002, 2012; Von Rad et al., 1999a, 2002b). These studies revealed strong teleconnections with North Atlantic climate variations reflecting, for example, Dansgaard-Oeschger and Heinrich events during the last glacial period (Deplazes et al., 2014; Reichart et al., 1997; Schulz et al., 1998).

\footnotetext{
'Department of Biogeochemistry and Geology, Leibniz Centre for Tropical Marine Research, Germany

2University of Bremen, Faculty of Geosciences, Bremen, Germany 3 Institute for Geology, Universität Hamburg, Germany ${ }^{4}$ Bundesanstalt für Geowissenschaften und Rohstoffe (BGR), Germany

${ }^{5}$ Geology Division, National Institute of Oceanography, India

${ }^{6}$ Senckenberg Centre for Human Evolution and Palaeoenvironment (HEP), Universität Tübingen, Germany

${ }^{7}$ Alfred Wegener Institute Helmholtz Centre for Polar and Marine Research, Germany

8MARUM - Center for Marine Environmental Sciences, University of Bremen, Germany
}

\section{Corresponding author:}

Birgit Gaye, Institute for Geology, Universität Hamburg, Bundesstraße 55, D-20l46 Hamburg, Germany.

Email: birgit.gaye@uni-hamburg.de 


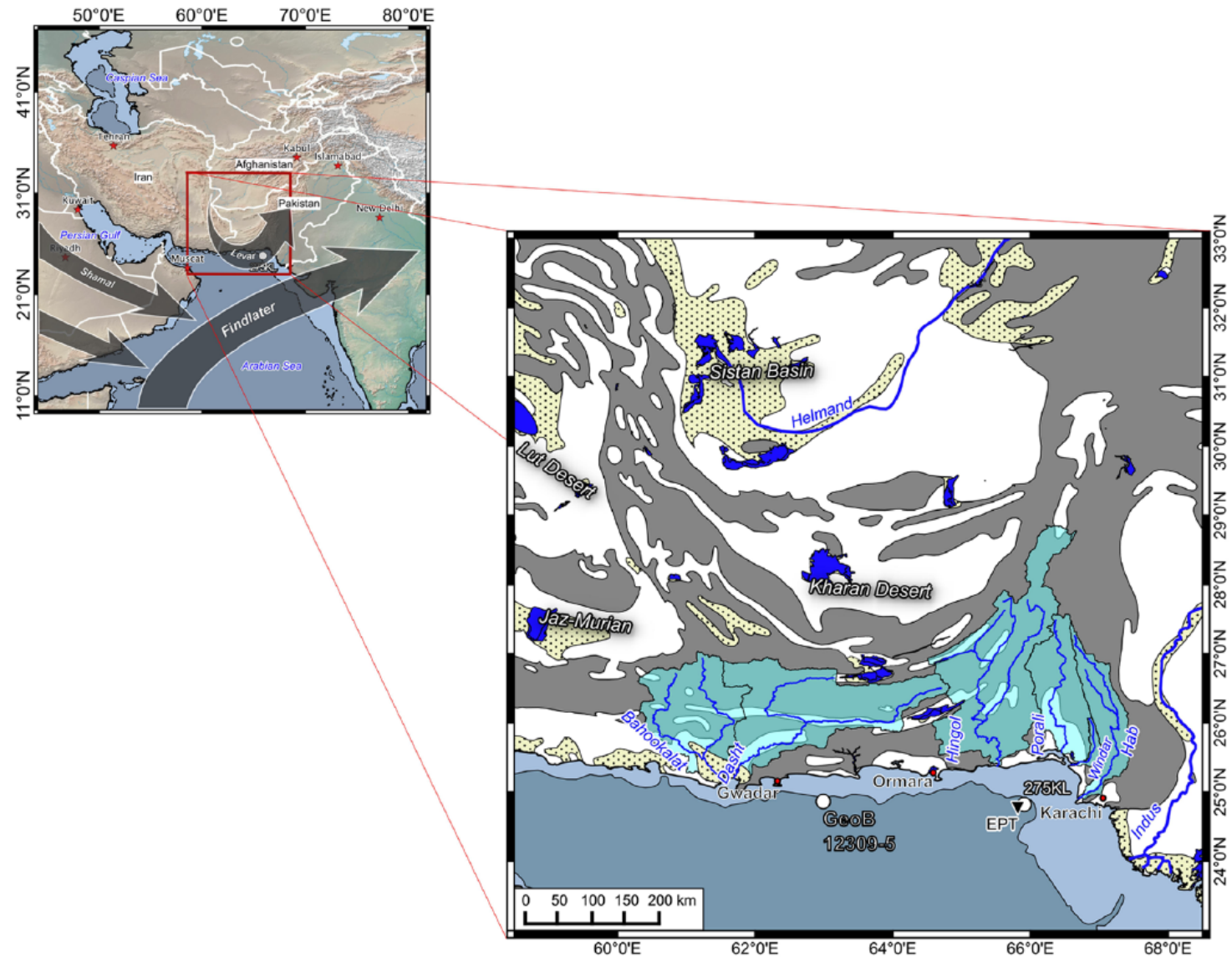

Figure I. Study area in the context of the Arabian Sea realm. Arrows indicate the major wind systems during the southwest monsoon season. The track of the mineral dust-laden Levar wind, which distributes huge amounts of Sistan dust over the Sistan Basin, is redrawn from Rashki et al. (20I5). Grey areas signify bedrocks, stippled yellow areas potential dust sources characterized by hydrologic generated sediments (i.e. alluvial and salt soils). Major dust sources are located in the desert basins of Sistan, Kharan, Lut and Jaz-Murian. Shallow hamuns, rivers and wadi streams are illustrated in dark blue, river basins in bright blue. The white circle and black triangle constitute the studied sites of core $275 \mathrm{KL}$ and sediment trap EPT-II, respectively. Lineament of red outlined circles and triangles mark coordinates for point data sampling sites illustrated in Figure 2.

Contrary to the western and central Arabian Sea, where at present regional dust storms are the main source of lithogenic matter (e.g. Kolla and Biscaye, 1977; Sirocko and Sarnthein, 1989; Stewart et al., 1965), local river discharges are assumed to be the main source of lithogenic matter to the northern and northeastern Arabian Sea (Lückge et al., 2001, 2002; Schulz et al., 2002; Staubwasser and Sirocko, 2001; Von Rad et al., 2002b). However, satellite imagery (Kaskaoutis et al., 2014, 2015; Rashki et al., 2013, 2015) in combination with modelled dust deposition rates (Mahowald et al., 2005) suggest that eolian dust might also contribute to the annual lithogenic matter sedimentation off Pakistan.

Within the laminated sediments, thicker whitish (referred to as C-Event layers) and reddish layers (F-Event layers) frequently interrupt the normal sedimentation of laminae described in detail by Schulz et al. (1996). C-Event layers were identified by Lückge et al. (2002) to be triggered by flash flood events following heavy rainstorms in the hinterland and the coast of Makran, as observed in March 1998 in the Turbat district of southern Balochistan (IFRC, 1999; Lückge et al., 2002). F-Event layers are coarser than $\mathrm{C}$-layers, sometimes graded and are clearly distinct from C-layers by their reddish colour (Schulz et al. 1996). They were suggested to be deposited by turbidity flows (Schulz et al., 1996; Von Rad et al., 1999a) with their main depot centres on the continental slope and abyssal plain throughout the Holocene but with changing frequencies, thickness and grain sizes induced by climate change in the hinterland (Bourget et al., 2010, 2011, 2013). According to Bourget et al. (2010), turbidites are deposited along the Makran coast even at mid- and late-Holocene sea-level highstands but with reduced frequency and thicker turbidites compared with the glacial and early Holocene. During the rising sea levels of the early Holocene, much of the terrestrial material contributed mainly by rivers was stored on the shelf and was only occasionally transferred to the deep sea. This trend to thicker and coarser turbidites became enhanced after the mid-Holocene humid period when the decrease in vegetation led to enhanced erosion (Bourget et al., 2010).

In this study, we investigated sediment samples obtained from sediment core SO130-275KL taken at a water depth of $782 \mathrm{~m}$ offshore Pakistan (Figure 1) close to the well-studied core SO9056KA (Von Rad et al., 1999a). The aim of this study is to characterize the variability of lithogenic matter sources of the last $5 \mathrm{ka}$ at the Makran coast by analysing grain-size distributions (GSDs) in varves and event layers and determine sediment sources by endmember modelling and comparison of results with local eolian dust, Hingol river bed sediments as well as sinking particles from a near-by sediment trap investigation (Schulz et al., 2002; Schulz and Von Rad, 2014). In combination with biogeochemical and mineralogical methods, we identify sources of organic matter, carbonate and lithogenic components and try to better understand the source and depositional processes of land-derived material. We use these results to quantify the significance of sedimentation 


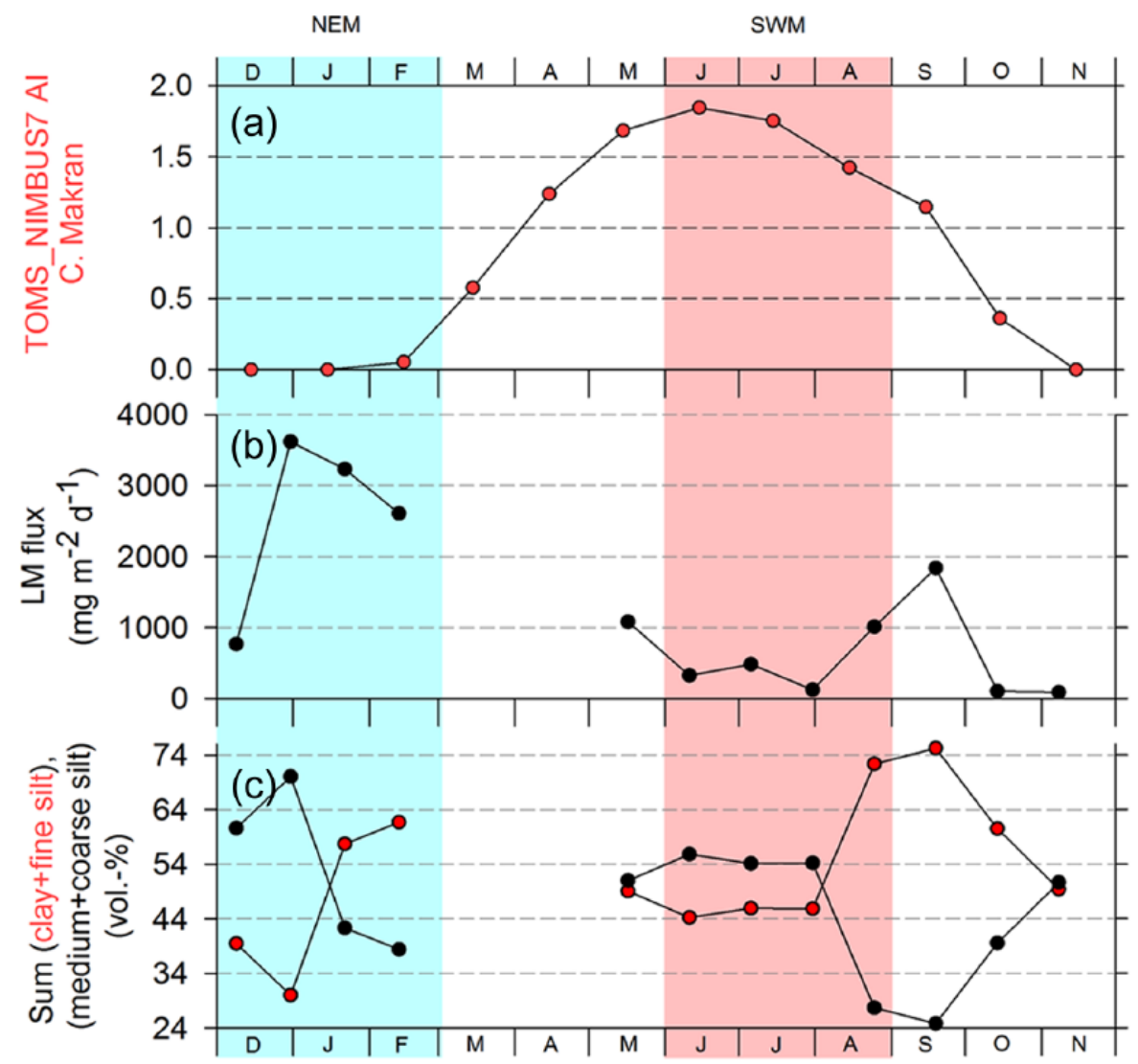

Figure 2. Comparison of averaged monthly (a) TOMS Al of northern and central Makran, (b) total lithogenic matter (LM) flux of EPT-II between 1993 and 1996, (c) sum of clay and fine silt (red dots) and medium and coarse silt (black dots) as proxies for distal dust and fluvial mud. Blue bars $=$ NE monsoon season, red bar $=$ SW monsoon season.

events compared with annual varve deposition of the past 5000 years as recorded in sediment core $275 \mathrm{KL}$.

\section{Study area}

The Arabian Sea is strongly influenced by the Indian monsoon, which is driven by the differential summer-heating and wintercooling of the Asian land mass and the Indian Ocean (Ramage, 1987). In summer (SW monsoon season), strong heating forms an atmospheric low over central Asia that attracts the SE trade winds to form a low-level cross-equatorial jet stream, blowing from the southwest over the Arabian Sea (Figure 1, Findlater, 1977). This so-called Findlater Jet causes upwelling off Oman, which is the major process in the Arabian Sea controlling biological productivity and the associated export of organic matter from the sunlit surface ocean into the deep sea during the summer monsoon (Brock et al., 1991, 1992; Rixen et al., 2000, 2009). The monsoon-driven export of organic matter and its respiration in combination with a restricted circulation within the permanent thermocline form and maintain an oxygen minimum zone, which is most pronounced at water-depths between 100 and $1000 \mathrm{~m}$ in the northern part of the Arabian Sea (Bogus et al., 2012; Fischer et al., 2013; Gaye et al., 2013; Rixen et al., 2014; Rixen and Ittekkot, 2005; Sen Gupta et al., 1976; Wilhelms-Dick et al., 2012). Off Pakistan, where the oxygen-deficient water flushes the continental slope, dark-olive and bright alternating laminated sediments are formed due to a reduced bioturbation in the absence of higher organisms avoiding such oxygen-deficient waters (e.g. Von Rad et al., 1999b).

Our studied core is located about $60 \mathrm{~km}$ south of the eastern Makran coast, at the easternmost part of the active Makran accretionary wedge that is formed by the subduction of the
Arabian under the Eurasian Plate. The Makran subduction zone is an area of frequent earthquake activity with a recurrence time of high-magnitude earthquakes of 125-250 and a presumed part of the two main tsunamigenic zones in the Indian Ocean (e.g. Fischer et al., 2013; Heidarzadeh et al., 2008, 2009; Page et al., 1979), which left traces in the sedimentary records along the shores of the northern Arabian Sea (e.g. Donato et al., 2009; Koster et al., 2014). However, sediment supply to the submarine environment of the active Makran margins is preferentially controlled by seasonal short river systems that are very sensitive to climate changes (Bourget et al., 2010, 2011, 2013).

The bathymetry off Makran is composed of a dense dendritic network of prominent river-erosive channels or canyons that cut a high tectonic relief of accreted ridges and intra-slope basins. These channels were most probably incised during sealevel lowstands and are located directly off the many ephemeral streams and the few perennial rivers such as the Hingol and Hab (Bourget et al., 2011). Even at the present sea-level highstand, these channels funnel gravity flows of material intermittently stored on the shelf and upper slope (Bourget et al., 2010, 2011). Multi-beam bathymetry reveals that our core study site is located on the interfluve between two small canyons that were possibly incised by the river systems of the Phor and Porali rivers (compare core site 56KA of Figure 2 in Bourget et al., 2010). Besides the Phor and Porali rivers, the perennial Hingol river is suggested as the main sediment supplier to the coring site (Lückge et al., 2001), whereas the Hab and Indus rivers do not contribute significantly as the prevailing clockwise surface circulation diverts their river plumes to the southeast during the SW-monsoon induced discharge maximum (Lückge et al., 2001; Von Rad and Tahir, 1997). 
The land area north of the Arabian Sea (Balochistan) covers large parts of Pakistan and Iran (Figure 1). Balochistan and the northerly adjacent area of Sistan are important sources of dust and river runoff because of their dry climate, tectonic activities, low or absent soil protection by vegetation, weakly consolidated geological strata and the steep topographic gradient between the coastal mountain ranges and the coast (e.g. Field et al., 2009; Lückge et al., 2002; Milliman and Farnsworth, 2011). Contrary to the monsoon-dominated areas to the south of Balochistan, which experience most rainfall during the summer monsoon, the rainy season in the northern and western parts of Balochistan occurs in winter between December and February/ March. This is caused by the southward shift of the climate zones in winter, which brings Balochistan into the influence of the upper tropospheric subtropical westerly jet (SWJ). The SWJ carries humid cyclonic storms from the Mediterranean and the Atlantic Ocean eastward and feeds the winter rainfall over Balochistan often referred to as WD (e.g. Dimri et al., 2015; Hastenrath, 1996; Prasad and Enzel, 2006; Roberts and Wright, 1993; Weyhenmeyer et al., 2000). At present, the Hingol river marks the frontier between areas influenced by summer and winter rains and is accordingly fed by precipitations during both seasons (Snead, 1968). Nevertheless, winter precipitation predominates and occasionally reaches alarming quantities causing highly erosive flash floods that dump their loadings into the Arabian Sea. Processes triggering these events are still poorly understood, but there are attempts to link their occurrence with anomalies in the coupled ocean atmospheric circulation such as the North Atlantic Oscillation (NAO) and the El Niño Southern Oscillation (ENSO) (e.g. Dimri, 2013; Dimri et al., 2013; Syed et al., 2006, 2010). Positive phases of NAO are assumed to cause drought in the Eastern Mediterranean region as well as in central and southern Iran, but lead to excess precipitation further to the north-east over the Hindu Kush Mountains in Afghanistan and the north-western parts of Pakistan (Syed et al., 2010). Excess precipitation over this region and the western Himalayas are also associated with positive ENSO phases, that is, El Niño events (Dimri et al., 2015; Syed et al., 2006, 2010; Yadav et al., 2013). During a strong El Niñoassociated precipitation event in March 1998, a devastating flood that formed a thick C-Event layer off Ormara could be observed (IFRC, 1999; Lückge et al., 2002).

During the summer season, a northerly low-level jet, called the Levar or 120-day winds (up to $200 \mathrm{~km} / \mathrm{h}$; Alizadeh-Choobari et al., 2013), develops due to the strong summer heating that enforces a convective low-pressure system (Figure 1; Rashki et al., 2015). The Levar winds mobilize easily erodible silts and clays from dried-up rivers and lakes, which often leads to heavy dust storms (e.g. Prospero et al., 2002; Rashki et al., 2013; Rezazadeh et al., 2013; Whitney, 2006). In the Sistan Basin, which is considered to be one of the main dust sources in the region, the number of dust storms often exceeds 80 during a single summer monsoon season (Goudie and Middleton, 2000; Middleton, 1986). The dust storm intensities in the Sistan Basin are strongly linked to the aerosol loading over the northern Arabian Sea (Kaskaoutis et al., 2014). At the confluence of the Levar winds carrying the dust southward towards the Makran coast and the Findlater Jet, decreasing wind speeds favour dust deposition and restrict dust dispersion within the monsoon system (Figure 1; Sirocko and Sarnthein, 1989).

\section{Materials and methods}

\section{Material and accumulation rates}

We investigated the upper $428 \mathrm{~cm}$ of the piston core $275 \mathrm{KL}$ $\left(24^{\circ} 49.31^{\prime} \mathrm{N}, 65^{\circ} 54.60^{\prime} \mathrm{E} ; 782 \mathrm{~m}\right.$ water depth), which was retrieved in 1998 from the oxygen minimum zone at the Pakistani continental slope during cruise SO130 with the German research vessel RV Sonne (MAKRAN II Cruise Report, 1998). The sediments of the piston core show no indications of erosion by turbidity or bottom currents and thus characterize $275 \mathrm{KL}$ as an almost undisturbed record of Holocene sedimentation off Pakistan. The PAKOMIN sediment trap EPT-II $\left(24^{\circ} 45.6^{\prime} \mathrm{N}, 65^{\circ} 48.7^{\prime} \mathrm{E} ; 537 \mathrm{~m}\right.$ water depth) was moored close to the core site of $275 \mathrm{KL}$ (Figure 1, about $12 \mathrm{~km}$ distance) from May 1995 to October 1996. Due to technical problems (clogging), the obtained sediment trap record covered only the period between May 1995 and February 1996 (Figure 2; Andruleit et al., 2000). Annual averages used in this work were calculated based on the available data set of about 10 months. As we will discuss below, the effect of undertrapping by shallow sediment traps is more significant than the effect of missing 2 months of sampling. As an example of Makran rivers, we analysed lower Hingol river flood terrace sediments provided by the BGR Hannover, Germany (for further references, see Lückge et al., 2001). Geochemically and mineralogically, these flood terrace sediments strongly resemble lithogenic matter of central Makran obtained from sediment core GeoB12309-5 off the Dasht river $\left(24^{\circ} 25.3^{\prime} \mathrm{N}, 62^{\circ} 59.9^{\prime} \mathrm{E}\right.$; $956 \mathrm{~m}$ water depth; Wilhelms-Dick et al., 2012).

The sediment core $275 \mathrm{KL}$ was sampled in approximately $3-\mathrm{cm}$ intervals and the white and reddish events were sampled separately. Chronostratigraphy is based on eye-to-eye correlations with 99 event layers of core SO90-56KA from the same location (distance to $275 \mathrm{KL}<1.5 \mathrm{~km}$ ), which was dated by 'varve' counting in combination with the AMS ${ }^{14} \mathrm{C}$ method and conventional radiocarbon ages (detailed methodology described by Munz et al., 2015; Von Rad et al., 1999a). The standard deviations of the AMS ${ }^{14} \mathrm{C}$ dates and conventional radiocarbon ages were between 31-51 years and 140-205 years (Von Rad et al., 1999a), respectively, but the counting of annual varves and two additional exact dates of the Krakatoa and Tambora ash layers resulted in virtually exact ages for SO90-56KA. The obtained ages are displayed in years before present (yrs BP), meaning before AD 1950 (Supplements S1 and S2, available online). The ages of C- and F-layers of SO90-56 KA were transferred to the event layers found in core SO130-275 KL and the ages between these events were linearly interpolated. The age differences between individual event layers are between 2 and 441 years. The depths and ages of C- and F-Event layers are given in Supplement S1 (available online) and the core photograph with ages of C- and F-layers indicated is provided in Supplement S2 (available online)

Total mass accumulation rates (MAR) of the sediments were calculated by multiplying the linear sedimentation rate (LSR) with the dry bulk density (DBD). LSR ( $\mathrm{cm} / \mathrm{yr})$ was determined using age model depth and age interval values, whereas DBD (g/ $\mathrm{cm}^{3}$ ) was calculated as described by Avnimelech et al. (2001):

$$
D B D=\frac{\text { Weight dry sample }(W d)}{\text { Total sample volume }(V t)}
$$

where

$$
\begin{aligned}
V t & =\text { Volume of solids }+ \text { volume of water } \\
& =\frac{\text { weight dry sample }}{\text { particle density }}+\left(\begin{array}{l}
\text { weight wet sample } \\
\text {-weight dry sample }
\end{array}\right)
\end{aligned}
$$

For the calculation of sediment particle density, we assumed $2.65 \mathrm{~g} / \mathrm{cm}^{3}$ as conventionally used for inorganic sediment particles (Blake and Hartge, 1986; Boyd, 1995) and a density of $1 \mathrm{~g} / \mathrm{cm}^{3}$ was taken for water. Although organic matter weight percentages are below $5 \%$, we also performed a density correction for organic 
matter contents by assuming a density of $1.25 \mathrm{~g} / \mathrm{cm}^{3}$ for organic particles (Boyd, 1995):

$$
\begin{aligned}
& \text { Weighed average } \\
& \text { sediment particle density }=1.25(\% \mathrm{OM})+ \\
& 2.65(100 \%-\% \mathrm{OM})
\end{aligned}
$$

Prior to analysis of bulk components (organic matter, carbonate, biogenic opal and lithogenic matter) and mineral assemblage of lithogenic matter, the sediments were wet weighed, freezedried, dry weighed and finally an aliquot was ground and homogenized for analyses (see Böll et al. 2014 for details). Accumulation rates of the bulk components were determined by multiplying the total MAR with the analysed weight percentages of individual bulk components.

\section{Mineral assemblages}

X-ray diffraction (XRD) analysis on six C-Event samples of the piston core was done at the University of Bremen (Central Laboratory for Crystallography and Applied Material Sciences, ZEKAM, Department of Geosciences). An amount of $1 \mathrm{~g}$ of dried and ground bulk sample material was prepared with the Philips backloading system for measurements of x-ray diffractograms. Measurements were conducted on a Philips X'Pert Pro multipurpose diffractometer with a Cu-tube (1.541 ka, $45 \mathrm{kV}, 40 \mathrm{~mA})$, a fixed divergence slit of $1 / 4^{\circ}$, a secondary $\mathrm{Ni}$ filter and the $\mathrm{X}^{\prime}$ Celerator detector system. Measurements were done as continuous scans from 3 to $85^{\circ} 2$ e (calculated step size of $0.016^{\circ} 2 \theta$ with $50 \mathrm{~s}$ calculation time per step). For mineral identification, Philips software X'Pert HighScore ${ }^{\mathrm{TM}}$ was used; for identification of sheet silicates, MacDiff 4.25 was used (see Petschick et al., 1996 for details). Quantification of mineral assemblages was done with the full-pattern QUAX $^{\odot}$ software package (Vogt et al., 2002). Precision for the bulk mineral determination is $1 \%$ for quartz, $2-5 \%$ for feldspar and $5-10 \%$ for clay minerals.

\section{GSD parameters}

For grain-size analysis of sediment core material and Hingol river bed sediment, $250 \mathrm{mg}$ of the bulk sediment was freed from organic matter and carbonates by treatment with $\mathrm{H}_{2} \mathrm{O}_{2}$ (boiled up) and $\mathrm{HCl}$, which act as main cements of most sediments (e.g. Sun et al., 2002 and references therein). Afterwards, the sediments were boiled in water and Calgon ${ }^{\circledR}\left(\mathrm{Na}_{6} \mathrm{P}_{6} \mathrm{O}_{18}\right)$ dispersant to avoid particle coagulations. Ultrasonification was conducted before measurements by application of the particle size analyser. Grain size was measured on a Horiba LA-950 V2 laser-scattering particle size distribution analyser. GSDs were calculated for 93 grainsize classes within a measuring range of $10 \mathrm{~nm}$ to $3 \mathrm{~mm}$. Measurements were conducted three times per sample and then averaged. Mean grain-size spectra were calculated for varves, Cand F-Events layers and the standard deviation $(1 \sigma)$ from the mean grain-size spectra is $\pm 19 \%$ for varves, $\pm 25 \%$ for $\mathrm{C}$ - and $\pm 42 \%$ for F-Event layers, respectively. The GSD parameters were calculated using the GRADISTAT programme (Blott and Pye, 2001). End-member modelling was conducted using an endmember modelling analysis (EMMA) script for MATLAB (Dietze et al., 2012).

To test a potential impact of sediment alteration by the treatment method used on GSDs, 12 samples were measured without former chemical treatment (Supplementary material S3-S5, available online). We observed no systematic difference between the GSD in HCl-treated and untreated varve samples and surmise that this is due to the presence of carbonaceous shells of different species and sizes in addition to the more sorted lithogenic or pedogenic carbonates. There is a systematic difference between
HCl-treated and untreated C- and F-layers. C- and F-layers lose material in the clay and fine-silt fraction at $0.3-0.4 \mu \mathrm{m}$ and $2-3$ $\mu \mathrm{m}$ after $\mathrm{HCl}$ treatment. F-layers and one C-layer loose material at $15-30 \mu \mathrm{m}$ and F-layers lose material at 70 and $500 \mu \mathrm{m}$ after acid treatment. We surmise that the loss in the sand fraction is related to destruction of large aggregates, whereas carbonate dissolution occurs in the clay and fine-silt fraction. We did not remove biogenic opal from the sediments as the percentage was below $1 \%$ in all analysed samples with an average of $0.6 \%$ (see method and results in Böll et al., 2014) and, therefore, the effect of biogenic opal on the grain-size analyses is negligible.

Grain-size analysis of EPT settling sediments was conducted at the University of Hamburg, Germany, with a GALAI CIS 100 laser-scattering particle size analyser on particle sizes between 0.5 and $100 \mu \mathrm{m}$ on a resolution of $0.5 \mu \mathrm{m}$ (Tiemann, 2001). Measured samples were collected on grain-size ranges only $(<2,2-6$, 6-20 and 20-63 $\mu \mathrm{m}$ ) hindering direct comparison of GSDs with the other sediment types due to lacking resolution and the different instruments used.

The aerosol GSD data for Karachi were obtained from the Aerosol Robotic Network (AERONET; https://aeronet.gsfc.nasa. gov/new_web/index.html).

Note that due to the different methodologies, we can only discuss qualitative differences and trends in GSDs when comparing sediment trap and dust samples with Hingol river bed and sediment core samples.

\section{Stable oxygen and carbon isotope ratios}

Carbonate stable oxygen $\left(\delta^{18} \mathrm{O}\right)$ and carbon $\left(\delta^{13} \mathrm{C}\right)$ isotope measurements were conducted on aliquots of homogenized bulk C-Event layer material with a Finnigan Kiel IV Carbonate Device coupled to a Finnigan MAT251 mass spectrometer. For $\delta^{13} \mathrm{C}$ measurements on organic material of bulk sediment samples, we used a Finnigan Delta Plus gas isotope ratio mass spectrometer after removal of carbonates by $1-\mathrm{N}$ HCL and subsequent drying at $40^{\circ} \mathrm{C} . \delta^{13} \mathrm{C}$ and $\delta^{18} \mathrm{O}$ of carbonates and organic material are given as \%o deviation from the composition of the VPDB standard. The precisions measured by internal standards were $-0.01 \%$ for $\delta^{18} \mathrm{O}_{\text {carb }}, 0.11 \%$ for $\delta^{13} \mathrm{C}_{\text {carb }}$ and $0.14 \%$ for $\delta^{13} \mathrm{C}_{\text {org }}$.

\section{Nimbus-7 aerosol index}

We used the mean monthly Total Ozone Mapping Spectrometer (TOMS) aerosol index data provided by the World Climate Research Programme CLIVAR (Climate Variability and Predictability; www.ouce.ox.ac.uk/ clivar) over central Makran to investigate the mean monthly distribution of aerosols over Balochistan. The original data for index calculations are based on multispectral measurements in the ultraviolet (UV) wavelengths on board of the Nimbus-7 satellite between 1978 and 1993, received from the TOMS data page of the NASA (http://disc.sci.gsfc.nasa. gov/aerosols/data-access). The calculations for the aerosol index are described in detail by Herman et al. (1997).

\section{Results and discussion}

\section{Varve accumulation and composition}

The Levar winds develop parallel to the summer monsoon and control the dust concentration in the atmosphere over Balochistan and the coast of Makran (e.g. Rashki et al., 2015; Rezazadeh et al., 2013; Snead, 1968) with dust maxima between May and August (Figure 2a). Back-trajectory analysis identified the Sistan Basin as a major source region for aerosols over Karachi (Alam et al., 2012; Rashki et al., 2015). Grain-size analyses of aerosols collected in summer over Karachi show a unimodal distribution with a mean mode at $2.6 \mu \mathrm{m}$ (Figure $3 \mathrm{a}$ ), which is 


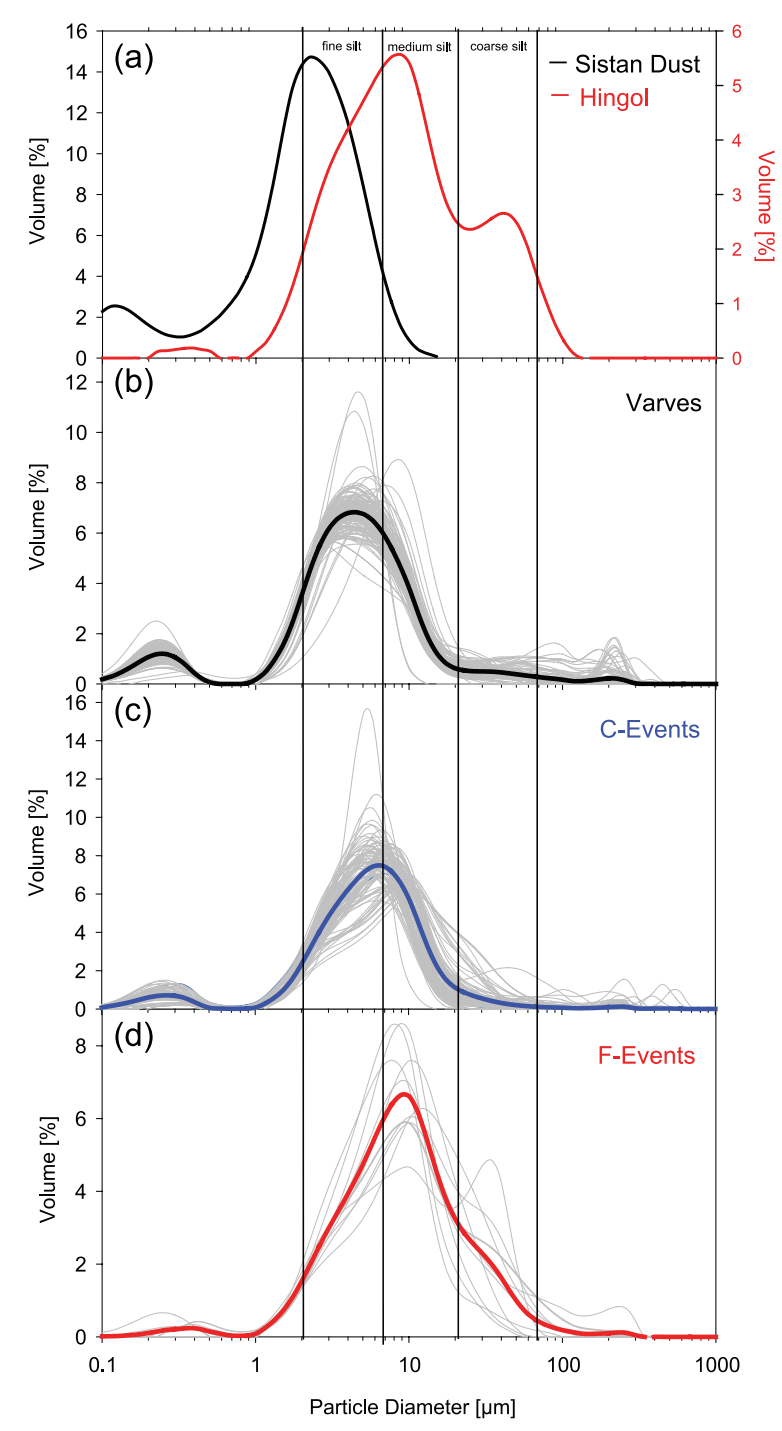

Figure 3. Comparison of grain-size distributions of (a) distal eolian dust measured by the ground-based remote-sensing method over Karachi (source: www.aeronet.gsfc.nasa.gov) and of the lower Hingol river flood terraces, (b) varves, (c) C-Event layers and (d) F-Event layers. Bold curves represent averages and grey curves represent individual samples.

generally considered to be characteristic for distal eolian dust (e.g. Mahowald et al., 2011, 2013; Pye, 1987; Seinfeld and Pandis, 2006). Contrary to distal Sistan dust, the Hingol river flood terrace sediment is coarser with a bimodal GSD (Figure 3a). The mean modes at 9 and $42.1 \mu \mathrm{m}$ probably reflect coarse suspended matter (Prins and Weltje, 1999) and bed load material (e.g. Billi, 2011; Reid and Laronne, 1995), respectively. Flood terrace sediments from other Makran rivers (not shown) are even coarser than the Hingol sample. However, the fine fraction is possibly not deposited on terraces and the river bed and also passes by the proximal cores off the river mouths. Therefore, it is underestimated in the river bed samples and proximal cores.

Mineral particles that are carried as eolian dust and as river suspended matter into the surface layer form the lithogenic matter fraction of sinking particles in the ocean (Honjo et al., 1982). The sediment trap EPT-II collected particles at $590 \mathrm{~m}$ water depth, which is approximately $1400 \mathrm{~m}$ above the seafloor, so that we can assume that its major source is particulate matter export from the surface layer (Schulz and von Rad, 2014). The lithogenic matter fluxes show a bimodal pattern with the maximum in winter (January-February) and a secondary maximum in late summer
(August-September; Figure 2b). During the observed summer monsoon of 1995, the lithogenic matter fluxes peaked in September 1 to 2 months after the atmospheric dust concentrations reached their maximum over marine regions close to the Makran Coast (Figure 2a). On the one hand, the delay could be explained by a weakening of the Levar winds during the declining summer monsoon that allows the dust to fall out (Rashki et al., 2015). On the other hand, the perennial Makran rivers as well as the Indus river (Ittekkot and Arain, 1986) also have SW-monsoon fed discharge maxima during August-September so that a riverine source of the fine material deposited in late summer cannot be ruled out. During winter, grain-size maxima suggest that the high lithogenic fluxes were associated with precipitation events and resulting discharges with flash floods of the Makran rivers (Lückge et al., 2002) (Figure 2c).

However, the seasonality of sedimentation of the fine lithogenic fraction is not solely controlled by the supply from eolian or fluvial sources but is driven by the seasonality of primary productivity as the export of fine-grained lithogenic material depends on its incorporation into fast sinking aggregates (Degens and Ittekkot, 1984; Ittekkot, 1993). These aggregates, referred to as marine snow and faecal pellets, are formed during plankton blooms (Alldredge and Silver, 1988; Osterberg et al., 1963; Silver and Alldredge, 1981; Suzuki and Kato, 1953), which are triggered by mixed-layer deepening caused by wintercooling, and advection of upwelled water from the Oman coast in summer (Rixen et al., 1996). The basic pattern of lithogenic sedimentation is thus a combined effect of the lithogenic matter supply and the monsoon-driven plankton blooms producing aggregates, which are the vehicles for the export of fine lithogenic matter into the deep sea.

Sediment traps are so far the only tool to measure the export of particles from the surface into the deep ocean and quantitative comparisons between trap results and sediments are biased by a variety of hydrodynamic, biological and chemical constraints (Buesseler et al., 2007 and references therein). Short-lived radionuclides and inverse modelling techniques used to estimate the accuracy of sediment traps indicate a generally strong undertrapping at continental slopes at depths between 200 and $1000 \mathrm{~m}$, with trapping efficiencies of 30-60\% (Buesseler et al., 2007; Schlitzer, 2000; Scholten et al., 2005; Usbeck et al., 2003; Yu et al., 2001). By taking a potential undertrapping of EPT-II between $30 \%$ and $60 \%$ into account, the corrected measured annual mean flux of lithogenic matter would rise from $357 \mathrm{~g} \mathrm{~m}^{-2} \mathrm{yr}^{-1}$ to values between 510 and $893 \mathrm{~g} \mathrm{~m}^{-2} \mathrm{yr}^{-1}$, respectively. This is well within the range of calculated varve MARs during the last 3700 years, which have a mean annual lithogenic matter MAR of $781 \mathrm{~g} \mathrm{~m}^{-2}$ $\mathrm{yr}^{-1}$ (Table 1). The composition of EPT-II samples is similar to varve compositions with, however, significant reductions in organic carbon and biogenic opal due to degradation and, respectively, dissolution in sediment (Table 1). Therefore, we assume that varves depict the normal sedimentation dominated by vertical flux of particles exported from the surface layer.

\section{Biogenic matter and carbonates in varves and C-Event layers}

C-Event layers differ from normal varve sedimentation by higher lithogenic matter and lower organic matter contents (Table 1). The visual inspection of smear slides shows that remains of marine plankton are abundant in varves, but absent in C-layers, suggesting that $\mathrm{C}$-layers are of terrigenous and varves are of a mixed marine and terrigenous origin (e.g. Lückge et al., 2002; Schulz et al., 1996). This view was supported by microscopic studies (Lückge, 1997), which showed that reworked material of higher land plants are the predominant contributors to the organic matter fraction in $\mathrm{C}$-Event layers. However, our mean $\mathrm{C} / \mathrm{N}$ values of 4.9 in combination with a mean organic matter $\delta^{13} \mathrm{C}$ value of 
Table I. Averaged lithogenic matter, carbonate, biogenic opal, organic matter and organic carbon $\left(\mathrm{C}_{\text {org }}\right)$ components (wt\%), mass accumulation and flux rates $\left(\mathrm{g} \mathrm{m}^{-2} \mathrm{yr}^{-1}\right)$ for $275 \mathrm{KL}$ (varves, C-layers and F-layers), EPT-Il trap sediments, and Hingol river samples (HR), respectively, and stable isotopic ratios of carbonate and organic carbon.

\begin{tabular}{|c|c|c|c|c|c|c|c|c|}
\hline & & Varves & C-layers & F-layers & EPT & $\mathrm{HR}$ & & \\
\hline \multirow[t]{2}{*}{ Lithogenic matter } & (wt\%) & 82.5 & 86.4 & 87.5 & 69.7 & 87.5 & & \\
\hline & $\left(\mathrm{g} \mathrm{m}^{-2} \mathrm{yr}^{-1}\right)$ & 781 & 4350 & 16,037 & 357 & & & \\
\hline \multirow[t]{2}{*}{ Carbonates } & (wt\%) & 14.4 & 12.5 & 10.4 & 16.4 & 12.3 & PI & Caliche \\
\hline & $\left(\mathrm{g} \mathrm{m}^{-2} \mathrm{yr}^{-1}\right)$ & 128 & 657 & 2217 & 69 & NA & Foram $^{\mathrm{a}}$ & Global $^{b}$ \\
\hline$\delta^{18} \mathrm{O}$ & (\%॰VPDB) & $-6.4^{c}$ & -6.4 & NA & NA & NA & -1.5 & -7.6 \\
\hline$\delta^{13} \mathrm{C}$ & (\%॰VPDB) & $-1.8^{c}$ & -3.1 & NA & NA & NA & -0.8 & -4.7 \\
\hline \multirow[t]{2}{*}{ Biogenic opal } & (wt\%) & $0.6^{\mathrm{d}}$ & NA & NA & 7.4 & NA & & \\
\hline & $\left(\mathrm{g} / \mathrm{m}^{2}\right)$ & $4.5^{d}$ & NA & NA & 35 & NA & & \\
\hline \multirow[t]{2}{*}{ Organic matter } & (wt\%) & 2.5 & I.I & 0.6 & 6.5 & 0.2 & & \\
\hline & $\left(\mathrm{g} \mathrm{m}^{-2} \mathrm{yr}^{-1}\right)$ & 24 & 40 & 39 & 23 & NA & & \\
\hline $\mathrm{C}_{\text {org }}$ & $(w t \%)$ & 1.4 & 0.7 & 0.3 & 3.2 & 0.1 & & \\
\hline $\mathrm{C} / \mathrm{N}$ & & 6.9 & 4.9 & 3.4 & 6.6 & 1.9 & & \\
\hline$\delta^{13} \mathrm{C}$ & (\%॰VPDB) & -21.0 & -22.1 & NA & NA & NA & & \\
\hline Total MAR & $\left(\mathrm{g} \mathrm{m}^{-2} \mathrm{yr}^{-1}\right)$ & 942 & 5011 & 24,918 & 484 & NA & & \\
\hline
\end{tabular}

MAR: mass accumulation rates; NA: not analysed.

a275KL.

${ }^{b}$ Averaged global values of Cerling (1984), Schlesinger et al. (1989) and Cerling and Quade (1993).

'Data of sediment core 53KG; for further information, see Von Rad et al. (1996).

dData from Böll et al. (20I4) covering the upper $188 \mathrm{~cm}$ of core $275 \mathrm{KL}$ (=2370 a BP).

$-22.1 \%$ traditionally point to a marine algal source (e.g. Meyers, 1997) (Table 1). Since $\mathrm{C} / \mathrm{N}$ ratios can be affected by nitrogen adsorbed to clay minerals (Meyers, 1997; Müller, 1977), a nitrogen correction was performed by plotting the organic carbon/clay size (particles $<2 \mu \mathrm{m}$ ) ratios versus $\mathrm{C} / \mathrm{N}$ ratios following the method of Hartmann et al. (1971) (Figure 4). The $\mathrm{C}_{\text {org }}$-poor Cand F-Event layers, as well as the Hingol river material, clearly show a significant decrease in $\mathrm{C} / \mathrm{N}$ below a $\mathrm{C}_{\text {org }} /$ clay ratio of about 0.14 probably due to an enrichment of nitrogen sorbed within clay minerals. $\mathrm{C} / \mathrm{N}$ ratios of samples with a $\mathrm{C}_{\text {org }}$ /clay ratio $>0.14$ are relatively stable and can thus be assumed to represent $\mathrm{C} / \mathrm{N}$ values of unprotected organic matter (Müller, 1977). However, varves and EPT-II sediments show no relationship between $\mathrm{C} / \mathrm{N}$ and $\mathrm{C}_{\text {org }} /$ clay ratios and thus indicate no or only minor impact of organic matter associated with clay minerals on nitrogen contents (Figure 4). The nitrogen correction results in $\mathrm{C} / \mathrm{N}$ ratios of 6 to 7.5 in C- and F-Event layers, which are close to those of phytoplankton and of the organic matter in varves and EPT-II (see Table 1). However, these values are also within the range of $\mathrm{C} / \mathrm{N}$ ratios measured in top soils of the north-eastern Tibetan Plateau (ratios of 5-25; Zhao et al., 2015). The $\delta^{13} \mathrm{C}$ values of degraded Tibetan soil organic matter varied between $-20 \%$ and $-26 \%$ so that the $\delta^{13} \mathrm{C}$ values of $-22 \%$ and $-21 \%$ measured in $\mathrm{C}$-Event layers and varves are within this range. $\mathrm{C} / \mathrm{N}$ ratios and $\delta^{13} \mathrm{C}$ values can, therefore, not be used to distinguish between organic matter produced by phytoplankton and eroded from terrestrial soils.

Carbonates, which contribute approximately between $12 \%$ and $16 \%$ to the varves, the C-Event layers and the sediment trap material offer a possibility to distinguish between marine and terrestrial sources as their stable isotope ratios differ (Table 1). The main carbonate producers in the Arabian Sea are coccolithophorids and foraminifera (Andruleit et al., 2000; Ramaswamy and Gaye, 2006; Schiebel et al., 2004). The stable isotope ratios $\left(\delta^{18} \mathrm{O}\right.$, $\delta^{13} \mathrm{C}$ ) of foraminifera picked from varves (unpublished data by $\mathrm{P}$ Munz) and other cores from the Arabian Sea (e.g. Lückge et al., 2001; Staubwasser et al., 2003) are $\sim-1.5 \%$ and $-0.8 \%$, respectively (Table 1). These values correspond with other stable isotope measurements of planktic foraminifera and coccolithophorids of the Holocene which basically preserve the stable isotopic values of water and the $\mathrm{CO}_{2}$ source with some species-specific differences due to vital effects (e.g. Fink et al., 2010; Rostek et al.,
1997). Fluctuations in foraminiferal $\delta^{18} \mathrm{O}$ can be affected by ice volume, temperature, salinity and circulation changes (Rajeev et al., 2012; Waelbroeck et al., 2006). The carbonates of the $\mathrm{C}$-Event layers are, however, more depleted in ${ }^{18} \mathrm{O}$ and ${ }^{13} \mathrm{C}$ than observable in recent marine carbonates with $\delta^{18} \mathrm{O}$ and $\delta^{13} \mathrm{C}$ values of $-6.4 \%$ and $-3.1 \%$, respectively (Table 1 ). Stable isotope measurements of bulk carbonates in varved sediments from box core SO90-53KG $\left(24^{\circ} 48.6^{\prime} \mathrm{N}, 65^{\circ} 54.9^{\prime} \mathrm{E}\right.$; water depth $850 \mathrm{~m}$; Von $\mathrm{Rad}$ et al., 1996), taken about $1.5 \mathrm{~km}$ from site $275 \mathrm{KL}$, show $\delta^{18} \mathrm{O}$ ratios that are identical to those measured in C-Event layers and $\delta^{13} \mathrm{C}$ ratio of $-1.8 \%$ between measured $\delta^{13} \mathrm{C}$ in foraminifera $(-0.8 \%)$ and C-Event layers $(-3.1 \%$, Table 1$)$. The differences between isotopic signatures seen in foraminifera and the bulk carbonates and the similarity between those seen in bulk carbonates and C-Event layers suggest that the carbonate sedimentation is substantially driven by isotopically light carbonates from land. Potential terrigenous sources for carbonates from Balochistan are marine outcrops along the Makran Ranges, evaporitic precipitates in hamuns or playas, and pedogenic soil carbonates (also known as caliche). Carbonates that formed under high evaporative conditions are generally enriched in the heavier isotopes ${ }^{18} \mathrm{O}$ and ${ }^{13} \mathrm{O}$ and thus reveal higher $\delta^{18} \mathrm{O}$ and $\delta^{13} \mathrm{C}$ values than those observed in C-Events (e.g. Quade et al., 2007; Stiller et al., 1985). Accordingly, they can be excluded as potential source material. In contrast, caliche of modern arid to sub-humid environments show a good accordance with the carbonates of varves and C-Event layers with a global mean $\delta^{18} \mathrm{O}$ value of $-7.6 \%$, and a global mean $\delta^{13} \mathrm{C}$ value of $-4.7 \%$ o (average values of Cerling, 1984; Cerling and Quade, 1993; Schlesinger et al., 1989). Soils from modern fluvial systems on the Indian subcontinent (Basu et al., 2018) have similar $\delta^{18} \mathrm{O}$ and $\delta^{13} \mathrm{C}$ values.

\section{Mineral assemblage and grain size of varves and event layers}

Silicates of C-Event layers are predominated by clay minerals with illite and chlorite as main contributors resembling the Hingol river sediments and other sediments of the Gulf of Oman (Table 2; Prins et al., 2000; Sirocko and Lange, 1991; Stewart et al., 1965). Chlorite is the characteristic of the Makran region and is restricted to areas close to its metamorphic or sedimentary source 
$\mathrm{C}_{\text {org }}$ /clay fraction $<2 \mu \mathrm{m}\left(\times 10^{3}\right)$
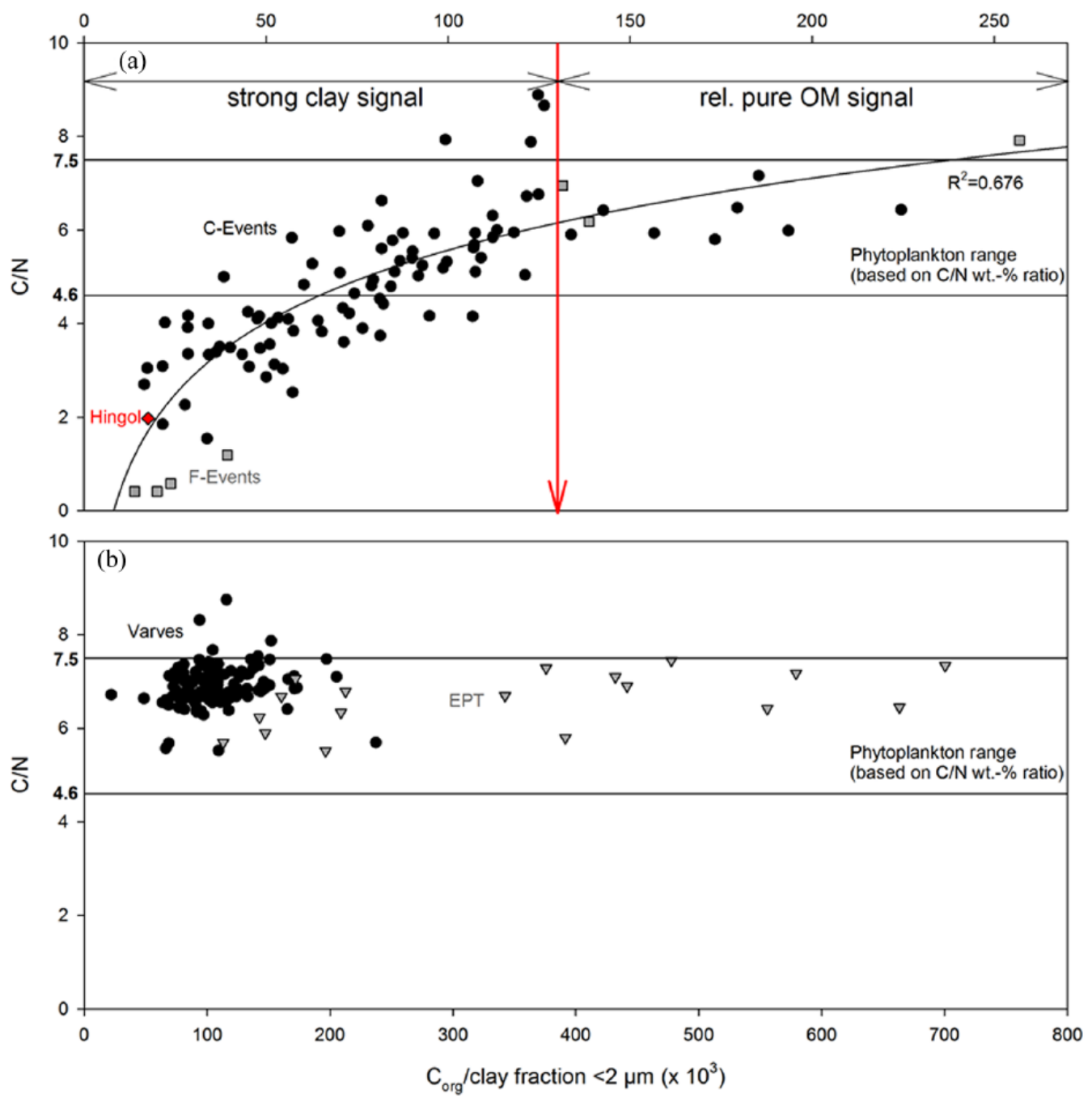

Figure 4. Relationships between $\mathrm{C} / \mathrm{N}$ wt\% ratios and organic carbon/clay ratios $\left(\times 10^{3}\right)$ as graphical correction for ammonium ions adsorbed on particles of the carbonate free clay size fraction $<2 \mu \mathrm{m}$, for (a) Hingol river sediments, C- and F-Event layers and (b) varves and EPT sediments. The red arrow indicates the organic carbon/clay threshold between values affected by nitrogen fixed within clay minerals to the left and independent values reflecting $\mathrm{C} / \mathrm{N}$ ratios of unprotected organic matter to the right. Method adopted from Hartmann et al. (197I).

region (Kolla et al., 1981). The absence of palygorskite and only low contributions of smectites indicate in line with other results that dust inputs from central Arabia via the Findlater Jet into the northeastern Arabian Sea are of minor importance (Kolla et al., 1976, 1981; Sirocko et al., 1991; Sirocko and Lange, 1991).

GSDs of silicates show uni- and bimodal patterns in varves and C-Event layers (Figure $3 \mathrm{~b}$ and $\mathrm{c}$ ). The fractions of silt and clay predominate in varves and C-Event layers by $97 \%$ (SD = $0.05 \%)$ and $99 \%(\mathrm{SD}=0.02 \%)$, respectively. Varves have the first or only mode (if unimodal) at about $4.8 \mu \mathrm{m}$ and the second mode at about $0.2 \mu \mathrm{m}$. Some varve samples are coarser with modes between 6 and $10 \mu \mathrm{m}$. C-Event layers have slightly coarser modes than varves at $0.3 \mu \mathrm{m}$ and around $7.2 \mu \mathrm{m}$. F-Events are mostly unimodal with modes between 8 and $11 \mu \mathrm{m}$. The only exception is a sample from the base of the youngest F-layer which has a second mode at $37 \mu \mathrm{m}$ in the coarse silt fraction corroborating that the F-layer is sorted and may originate from a turbidity flow.

For the end-member modelling with EMMA (see details of the method in Dietze et al., 2012) carried out on varve samples, three samples were excluded and are also not plotted in Figure $3 \mathrm{~b}$ as they are much coarser and have modes diverging from all samples and would thus have biased the end-member reconstruction. EMMA produces three main end-members which explain $87 \%$ of the total variance. End-member (EM) 1 has modes at 0.2 and 5 $\mu \mathrm{m}, \mathrm{EM} 2$ at 2.3 and $8 \mu \mathrm{m}$ and EM3 at 0.3 and $2.3 \mu \mathrm{m}$, respectively (Figure 5a). As Sistan dust has its mode at $2.6 \mu \mathrm{m}$ (Figure $5 \mathrm{c}$ ), we assume that EM3 represents the distal dust source. The mode of EM1 is close to the mode of about $6 \mu \mathrm{m}$ found in the EPT trap during the summer when monsoon impacted rivers have their discharge maxima (Tiemann, 2001). Therefore, we believe that EM1 represents river suspension. The mode of EM2 is close to the mode of F-layers (Figure 5b) and to the first mode of Hingol river bed sediments (Figure 5c; $9.5 \mu \mathrm{m}$; second mode: $42 \mu \mathrm{m}$ ) supposing that EM2 represents material originating from high energy transport mobilizing coarser material from the river beds or from the continental shelf and transporting it to the depot centres on the slope.

Grain-size spectra are not only affected by lithogenic matter sources but also by subaquatic transport energy (Bass et al., 2002; McCave, 2017; McCave and Hall, 2006). The absence of marine organisms and abundance of terrestrial organic matter imply an almost exclusive riverine origin for $\mathrm{C}$-layers in line with results of other authors using different methods (Lückge et al., 2001; Von 
Table 2. Average mineralogical composition of potential sediment sources, mean annual EPT-Il samples, surface samples $(0-2 \mathrm{~cm})$, varves of sediment core GeoBI2309-5 and C-Event samples of 275KL.Values are separated into principal and clay components and normalized to $100 \%$.

\begin{tabular}{|c|c|c|c|c|c|c|c|}
\hline Minerals & $\begin{array}{l}\text { Aerosols } \\
\text { Gwadar }\end{array}$ & $\begin{array}{l}\text { Hingol } \\
\text { river }^{b}\end{array}$ & $\begin{array}{l}\text { Average of lower } \\
\text { Indus riverc }\end{array}$ & $\begin{array}{l}\text { GeoBI2309 } \\
\text { Varves }^{\text {d }}\end{array}$ & $\begin{array}{l}275 \mathrm{KL} \\
\text { C-Events }\end{array}$ & $\begin{array}{l}\text { ME } 32 / 2 \\
\text { Surface }^{f}\end{array}$ & $\begin{array}{l}\text { EPT-II } \\
\text { Meang }\end{array}$ \\
\hline Quartz & 25.0 & 27.0 & 9.2 & 16.3 & 23.7 & 39.5 & 36.2 \\
\hline Feldspar & 13.3 & 11.2 & 11.2 & 7.7 & 13.8 & 14.8 & 9.0 \\
\hline Calcite & 29.5 & 12.9 & 3.6 & $16.7^{\mathrm{h}}$ & 12.8 & - & $13.4^{\mathrm{h}}$ \\
\hline Dolomite & 2.6 & 1.2 & 0.7 & 1.5 & 0.1 & 0.2 & 0.2 \\
\hline Clays & 29.7 & 47.7 & 75.5 & 57.8 & 49.6 & 45.5 & 41.3 \\
\hline Illite & 43.5 & 46.6 & 79.3 & 53.3 & $33.9^{i}$ & 67.2 & 70.3 \\
\hline Chlorite & 34.4 & 26.4 & 14.9 & 30.2 & $47.4^{i}$ & 23.4 & 24.0 \\
\hline Kaolinite & 15.6 & 14.3 & 2.4 & 11.3 & 13.4 & 2.1 & 5.2 \\
\hline Smectite & 6.5 & 12.7 & 3.5 & 5.2 & 5.4 & 7.3 & 0.5 \\
\hline
\end{tabular}

${ }^{a}$ Average of three sample locations of airborne dust in the vicinity of Gwadar.

bSample of lower Hingol river flood terrace sediments.

'Average of two sample locations of the lower of the Indus river plains.

'Average of IOI varve samples of sediment core GeoBI2309-5.

eAverage of six C-Event samples of core $275 \mathrm{KL}$.

fAverage of four mixed-surface samples taken close to the EPT and 275KL sites during METEOR cruise 32/2.

'Average of 27 EPT samples representing SW and NE monsoon seasons 1995/96.

hMixed organic and terrigenous calcite.

'Chlorite decreases and illite increases over time and converge to values of the recent Hingol river sediments.

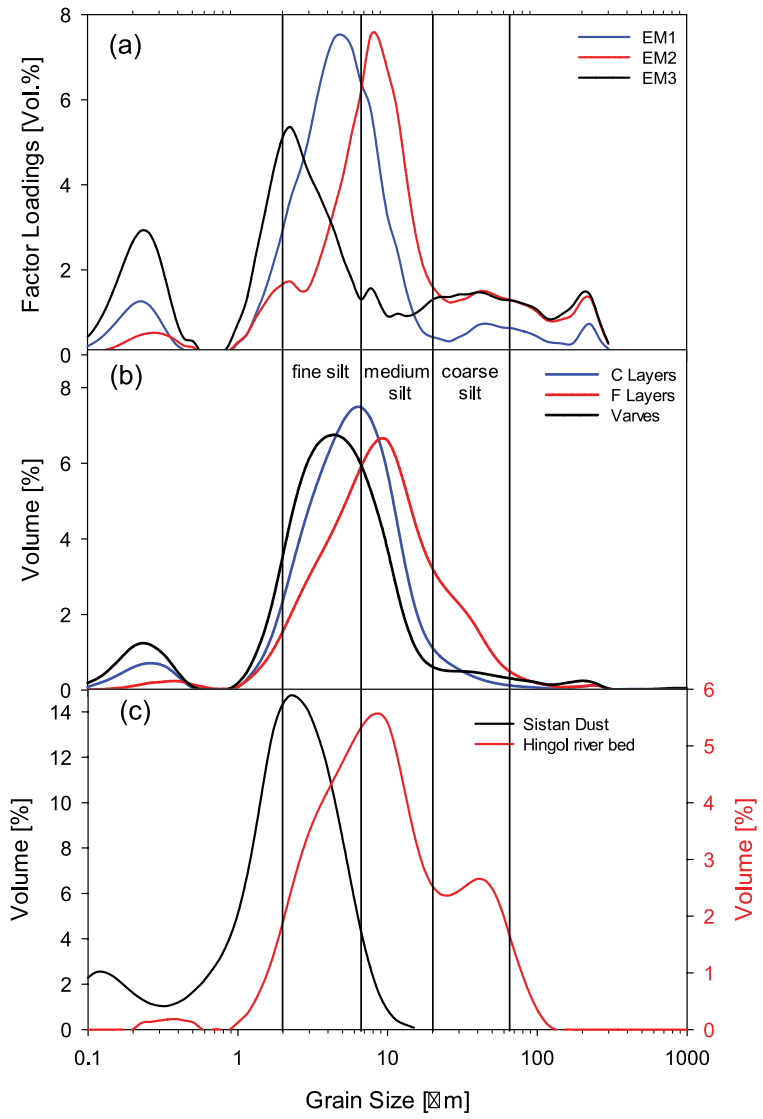

Figure 5. (a) Factor loadings of three end-members modelled with EMMA (Dietze et al., 2012) using grain sizes of varves compared with (b) mean grain-size distribution of varves, C-Event layers and F-Event layers and (c) grain-size distribution of Sistan Dust and Hingol river flood terrace samples.

Rad et al., 1999a, 2002a). Therefore, they must be transported directly from land by episodic river floods and probably reach the slope by under- or interflows (Von Rad et al., 2002a). This assumption was also made by Bourget et al. (2010) based on investigations of sediment cores west of $275 \mathrm{KL}$. Observations of hyperpycnal flows triggered by high-density river discharges into the northern Red Sea (Katz et al., 2015) suggest a likely mechanism for fast accumulation of terrigenous material that probably can explain the C-Event formation.

In line with results derived from bulk composition and stable isotopes, our results further imply that varves represent the 'normal' annual sedimentation with mixed marine and terrestrial inputs from both transport mechanisms fluvial and eolian into the surface water, subsequently subjected to packing and scavenging into biogenic settling aggregates (see above).

\section{F-Event layers}

Contrary to Schulz et al. (1996), who assumed F-Event layers to be exclusively of terrigenous origin, we also observed residues of marine plankton such as foraminifera and diatoms in the reddish sediments pointing to mass redistribution of marine and coastal deposits. Staubwasser and Sirocko (2001) stated that the geochemistry of the F-Event layers closely resembles that of sediments from the lower Indus river plains. Von Rad et al. (2002b), on the other hand, argued that the Indus river is a rather unlikely source for F-Event layer formation due to, for example, the long distance between the Indus mouth and the core site, and the prevailing current direction that diverts the Indus load southward. Due to their restricted occurrence in the northeastern-most part of the Arabian Sea (Schulz et al., 1996), F-Event sediments must be sourced by very local sediment deposits. Mean GSD parameters of F-Event layers point to a coarser composition than varves and C-Event layers and show a close relation to the lower Hingol river terrace material (Figures 3 and 5). The Windar and Porali river located between the Hingol and Indus river (Figure 1) carry reddish sediments from the Kirthar range to the Miani Lagoon to form massive subaquatic sand banks. Snead (1966) reported the complete disappearance of such massive sand banks sometimes between AD 1842 and 1890, which would agree to the most recent F-Event formation in the core $275 \mathrm{KL}$ at around $\mathrm{AD} 1887$. Local fishermen reported that heavy surf during the SW monsoon season and also large floods causing strong currents in the lagoon regularly remove and redistribute the bar sediments. A direct transport of that huge amount of sediment to the slope during one such flood event seems unlikely due to (1) the distance of approximately $90 \mathrm{~km}$ between the lagoon outlet and site $275 \mathrm{KL}$, (2) the F-Event layer thicknesses of up to $9 \mathrm{~cm}$ and (3) the low mean event layer recurrence interval 


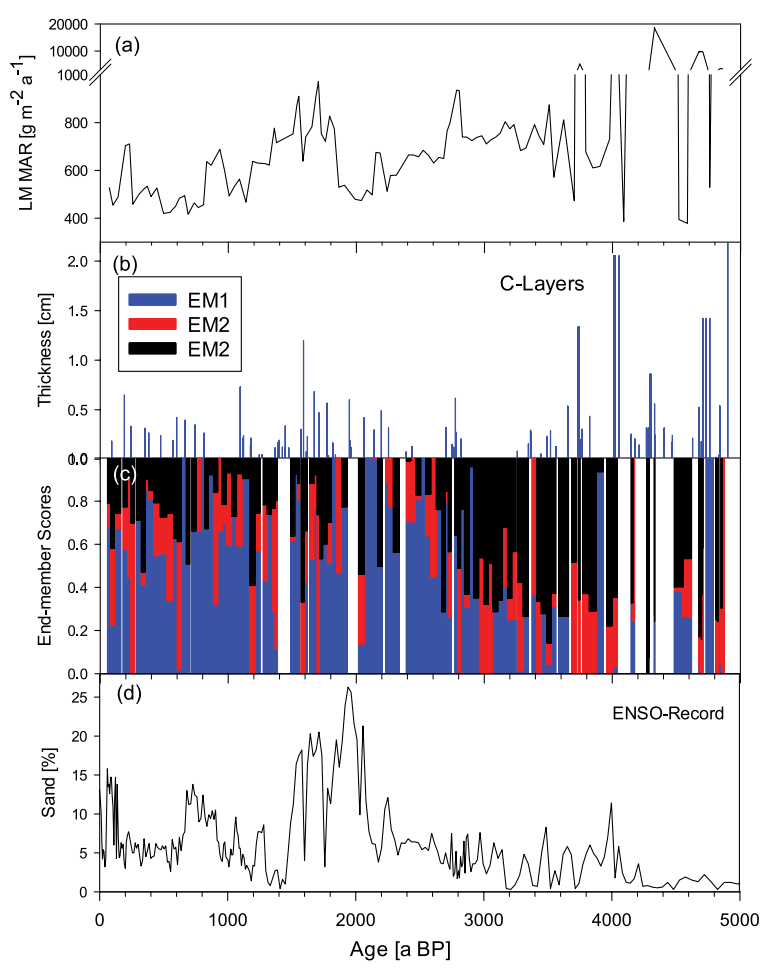

Figure 6. (a) Total lithogenic mass accumulation rates (LM MAR) of varves $\left(\mathrm{g} \mathrm{m}^{-2} \mathrm{a}^{-1}\right)$; (b) occurrence and thickness of $C$-Event layers (cm); (c) end-member scores of grain-size samples for the three end-members modelled with EMMA with EMI scores in blue, EM2 scores in red and EM3 scores in black; (d) ENSO record from a Galapagos lake with higher percentages of sand indicating wetter (positive ENSO) conditions (Conroy et al., 2008).

of ca. 491 (between 76 and 1041 years) during the past ca. 5000 years. Thus, we propose primary deposition of the reddish material on the shelf facilitated by alongshore currents that converge in front of the lagoon outlet from the north and the south creating an offshore suction (compare Figure 2 in Snead, 1966). Submarine landslides triggered by large-magnitude earthquakes (Fischer et al., 2013; Hampton et al., 1996) have mean calculated recurrence intervals between 175 and $>300$ years along the Makran subduction zone (Byrne et al., 1992) and are therefore a possible trigger for material re-deposition resulting in F-Event layer formation on the slope. Bourget et al. (2010) identified late-Holocene turbidite recurrence intervals of 200-235 years in regions receiving material directly via canyons, of 224 years in the deep abyssal plain, and of 308-500 years in two western isolated piggy-back basins, which resemble those of F-Event layers. Tsunami and tropical cyclone events may also trigger F-Event layer formation but there is no corresponding historical record connected with the youngest F-Event layer formation (Knapp et al., 2010; Rastogi and Jaiswal, 2006).

\section{Sediment mass budget}

In total, about $4.6 \mathrm{t} / \mathrm{m}^{2}$ sediments were accumulated at site $275 \mathrm{KL}$ during the past 4882 years producing a mean MAR of $983 \mathrm{~g} / \mathrm{m}^{2}$ yr. Lithogenic matter dominates the total sedimentation with $78 \mathrm{wt} \%$, followed in decreasing order by carbonates (14 wt \%), biogenic opal (6 wt\%) and organic matter (2 wt\%). Varve sedimentation is the major contributor and accounted for $89.3 \mathrm{wt} \%$ of the total sediment accumulation with a mean rate of $839 \mathrm{~g} / \mathrm{m}^{2}$ yr. Although a single F-Event layer comprises mean lithogenic matter and carbonate accumulation of 10 years of varve sedimentation, it contributes only $3 \mathrm{wt} \%$ to the total sediment amount of the past 5000 years. A C-Event layer deposits on average adequate to 6 years of normal varve sedimentation, but accounts for $7 \mathrm{wt} \%$ of the total sediments due to a higher recurrence interval of every 50 years compared to 491 years for F-Events.

\section{Variations in mid- and late-Holocene sediment sources and implications for climate change}

Lithogenic matter accumulation rates were extremely high with maxima between 10,000 and $18,000 \mathrm{~g} \mathrm{~m}^{-2} \mathrm{a}^{-1}$ and C-Event layers were thick and frequently deposited prior to about 4000 a BP (Figure $6 \mathrm{a}$ and $\mathrm{b}$ ). The results of the end-member mixing model showed that the varves were dominated by distal dust during this period (Figure 6c). This coincides with much drier conditions in the westerly wind belt as well as in the Indian monsoon zone proposed for the period from about 5000 to $4000 \mathrm{yr}$ BP (Lauterbach et al., 2014; Prasad et al., 2014). This prolonged dry spell following the Holocene climatic optimum was explained by a reduced import of summer moisture by mid-latitude westerlies (Lauterbach et al., 2014) and with a weakening of the Indian monsoon precipitation due to warming of the Indo-Pacific warm pool (Prasad et al., 2014). More arid conditions in both climatic realms, the westerly wind and the Indian monsoon region, could explain an enhanced supply of mineral matter from land due to enhanced erosion (e.g. Milliman and Farnsworth, 2011). After a period of strongly reduced C-Event layer deposition and a reduction in total accumulation rates to values below $1000 \mathrm{~g} \mathrm{~m}^{-2} \mathrm{a}^{-1}$, river suspension became the dominant constituent of varves after 2800 a BP indicating the return to more humid conditions (Figure 6c). As C-Event layers started to increase later at about 2300 a BP, we surmise that SW-monsoon precipitation increased earlier than the episodic winter rains producing C-Events layers. The second phase of elevated lithogenic matter accumulation rates between 1000 and 2000 a BP consisted mainly of fluvial material and coincides with a phase of enhanced occurrence of El Niño events (Figure 6d; Conroy et al., 2008) and with probably at the same time occurring positive NAO (Fletcher et al., 2012). Warm ENSO as well as positive NAO phases seem to significantly increase winter precipitation in the Makran region as it was suggested by models and recent observations (Dimri et al., 2015; Syed et al., 2006, 2010; Yadav et al., 2013). Enhanced precipitation during positive phases of the NAO may be triggered by a strengthened SWJ enhancing moisture transport from the Mediterranean and Atlantic (Syed et al., 2010). Warming of the Eastern Pacific during El Niño drags warm water from the western Pacific warm pool into the western Indian Ocean. This leads to a strengthening of the Hadley cell and at the same time to a stronger SWJ at the poleward end of the Hadley cell so that the WD induced winter rains over central southwest Asia are enhanced (Dimri, 2013; Dimri et al., 2016). These rains are additionally fed by enhanced moisture transport from a strong convective cell evolving from the abnormally warm western Indian Ocean (Dimri et al., 2015; Yadav et al., 2013). The establishment of a link with ENSO was also observed in the core monsoon zone at 2000 a BP where the positive ENSO phase leads to severe droughts (Prasad et al., 2014). It is very likely that the recent fluctuations in accumulation rates may be relatable to the intensities of winter precipitation and the West Pacific ENSO records (Figure 6a and $\mathrm{d}$ ), whereas the accumulation rate maximum between 4000 and 5000 a BP was caused by draught conditions.

\section{Summary}

Our results show that in summer, the south-eastward blowing Levar winds carry lithogenic matter, predominantly originating from Balochistan and the Sistan Basins, southward as dust to the 
northern Arabian Sea realm. In winter, river discharge is the predominant source of lithogenic matter, also on annual time scales. River discharge is fed by humid air masses that are transported eastward from the Mediterranean and the Atlantic Ocean and vary in concert with the NAO and ENSO due to associated changes in the configuration of the SWJ stream over southwest Asia in winter. End-member modelling of grain sizes and variations in lithogenic matter accumulation rates suggest that arid conditions prevailed between 4000 and 5000 a BP, while humid conditions commenced about 2000 a BP and winter precipitation feeding Makran rivers fluctuated in accordance with the ENSO record.

The whitish C-Event layers represent catastrophic denudation events related to flash floods that occurred on the coastal plains of Makran and on averaged recurrence intervals of 50 years. The reddish F-Event layers seem to be associated with massive relocation events of near shore sediments due to heavy earthquakes that resulted in turbidity flows and occurred only about every 500 years. Contrary to the F-Layers that contain material of marine and terrestrial origin, the C-Event layers are composed of mobilized river deposits and soil material. The soil material consists of pedogenic carbonates (referred to as caliche) and degraded soil organic matter. Stable carbon isotope and $\mathrm{C} / \mathrm{N}$ ratios measured in the degraded soil organic matter resemble those measured in marine plankton showing that these biogeochemical indicators cannot be used to quantify the contribution of terrestrial organic matter in marine sediments. Stable carbon and oxygen isotope ratios measured in the bulk carbonate of varves resemble those of carbonates in the C-Event layers and differ from those measured in shells of marine calcifying organisms, which suggest that lithogenic carbonate dominates within all sediment types along the Makran coast. Although individual C- and F-Event layers supply high amounts of material, their total contribution to sediment accumulation is only about $10 \%$ due to their low frequencies.

\section{Acknowledgements}

The authors thank the BGR Hannover for provision of the untreated SO130-275KL sediment core material and Dr Jörg Tiemann for grain-size data of sediment trap EPT-II. Katharina Pilgram, Dorothee Dasbach, Matthias Birkicht and Dr André Klicpera are thankfully acknowledged for their support in the laboratories. The authors also thank all members of the CARIMA project for their general assistance and openness to discussion. They are grateful to the two anonymous reviewers for their constructive comments and suggestions to improve the quality of the manuscript.

\section{Funding}

This work was funded by the German Ministry of Education and Research (BMBF) grant 03G0806C (CARIMA) and 03G0864A (CAHOL). The data are available at PANGAEA (Gaye, Birgit, 2018: Composition and grain size distribution of laminated sediment core SO130 275KL from northeastern Arabian Sea off Pakistan. https://doi.pangaea.de/10.1594/PANGAEA.894293).

\section{ORCID iD}

Philipp Munz (iD https://orcid.org/0000-0002-3149-0546

\section{References}

Alam K, Trautmann T, Blaschke T et al. (2012) Aerosol optical and radiative properties during summer and winter seasons over Lahore and Karachi. Atmospheric Environment 50: 234-245.

Alizadeh-Choobari O, Zawar-Reza P and Sturman A (2013) Low level jet intensification by mineral dust aerosols. Annales Geophysicae 31(4): 625-632.

Alldredge AL and Silver MW (1988) Characteristics, dynamics and significance of marine snow. Progress in Oceanography 20: $41-82$.
Andruleit HA, von Rad U, Brans A et al. (2000) Coccolithophore fluxes from sediment traps in the northeastern Arabian Sea off Pakistan. Marine Micropaleontology 38: 285-308.

Avnimelech Y, Ritvo G, Meijer LE et al. (2001) Water content, organic carbon and dry bulk density in flooded sediments. Aquacultural Engineering 25: 25-33.

Bass SJ, Aldridge JN, McCave IN et al. (2002) Phase relationships between fine sediment suspensions and tidal currents in coastal seas. Journal of Geophysical Research-Oceans 107: 14 .

Basu S, Sanyal P, Sahoo K et al. (2018) Variation in monsoonal rainfall sources (Arabian Sea and Bay of Bengal) during the late Quaternary: Implications for regional vegetation and fluvial systems. Palaeogeography, Palaeoclimatology, Palaeoecology 491: 77-91.

Billi P (2011) Flash flood sediment transport in a steep sandbed ephemeral stream. International Journal of Sediment Research 26(2): 193-209.

Blake GR and Hartge KH (1986) Bulk density. In: Black CA (ed.) Methods of Soil Analysis: Part 1-Physical and Mineralogical Methods, Including Statistics of Measurement and Sampling, Agronomy Monograph. Madison, WI: American Society of Agronomy, Soil Science Society of America, pp. 363-375. Available at: https://www.soils.org/publications /books/abstracts/sssabookseries/methodsofsoilan1/363.

Blott SJ and Pye K (2001) GRADISTAT: A grain size distribution and statistics package for the analysis of unconsolidated sediments. Earth Surface Processes and Landforms 26: 1237-1248.

Bogus KA, Zonneveld KAF, Fischer D et al. (2012) The effect of meter-scale lateral oxygen gradients at the sedimentwater interface on selected organic matter based alteration, productivity and temperature proxies. Biogeosciences 9(4): $1553-1570$.

Böll A, Lückge A, Munz P et al. (2014) Late-Holocene primary productivity and sea surface temperature variations in the northeastern Arabian Sea: Implications for winter monsoon variability. Paleoceanography 29(8): 778-794.

Bourget J, Zaragosi S, Ellouz-Zimmermann N et al. (2011) Turbidite system architecture and sedimentary processes along topographically complex slopes: The Makran convergent margin. Sedimentology 58: 376-406.

Bourget J, Zaragosi S, Ellouz-Zimmermann S et al. (2010) Highstand vs. lowstand turbidite system growth in the Makran active margin: Imprints of high-frequency external controls on sediment delivery mechanisms to deep water systems. Marine Geology 274: 187-208.

Bourget J, Zaragosi S, Rodriguez M et al. (2013) Late Quaternary megaturbidites of the Indus Fan: Origin and stratigraphic significance. Marine Geology 336: 10-23.

Boyd CE (1995) Bottom Soils, Sediment, and Pond Aquaculture. New York: Chapman \& Hall. Available at: http://books .google.de/books?id=7j0Zx8NHVgIC.

Brock JC, McClain CR and Hay WW (1992) A southwest monsoon hydrographic climatology for the northwestern Arabian Sea. Journal of Geophysical Research: Oceans 97(C6): 9455-9465.

Brock JC, McClain CR, Luther ME et al. (1991) The phytoplankton bloom in the northwestern Arabian Sea during the southwest monsoon of 1979. Journal of Geophysical Research: Oceans 96(C11): 20623-20642.

Buesseler KO, Antia AN, Chen M et al. (2007) An assessment of the use of sediment traps for estimating upper ocean particle fluxes. Journal of Marine Research 65(3): 345-416.

Byrne DE, Sykes LR and Davis DM (1992) Great thrust earthquakes and aseismic slip along the plate boundary of the 
Makran subduction zone. Journal of Geophysical Research 97: 449-478.

Cerling TE (1984) The stable isotopic composition of modern soil carbonate and its relationship to climate. Earth and Planetary Science Letters 71(2): 229-240.

Cerling TE and Quade J (1993) Stable carbon and oxygen isotopes in soil carbonates. In: Climate Change in Continental Isotopic Records (Geophysical Monograph Series). Washington, DC: AGU, pp. 217-231. Available at: http://dx.doi .org/10.1029/GM078p0217.

Conroy JL, Overpeck JT, Cole JE et al. (2008) Holocene changes in eastern tropical Pacific climate inferred from a Galapagos lake sediment record. Quaternary Science Reviews 27: $1166-1180$.

Degens ET and Ittekkot V (1984) A new look at clay-organic interactions. In: Degens ET, Krumbein WE and Prashnowsky AA (eds) Ein Nord-Süd Profil: Zentraleuropa-MittelmmeerraumAfrika. Stade: Mitteilungen aus dem Geologisch-Paläontologischen Institut der Universität Hamburg, pp. 229-248.

Deplazes G, Lückge A, Stuut J-BW et al. (2014) Weakening and strengthening of the Indian monsoon during Heinrich events and Dansgaard-Oeschger oscillations. Paleoceanography 29: 99-114.

Dietze E, Hartmann K, Diekmann B et al. (2012) An end-member algorithm for deciphering modern detrital processes from lake sediments of Lake Donggi Cona, NE Tibetan Plateau, China. Sedimentary Geology 243: 169-180.

Dimri AP (2013) Interannual variability of Indian Winter Monsoon over the western Himalayas. Global and Planetary Change 106: 39-50.

Dimri AP, Niyogi D, Barros AP et al. (2015) Western disturbances: A review. Reviews of Geophysics 53(2): 225-246.

Dimri AP, Yasunari T, Kotlia BS et al. (2016) Indian winter monsoon: Present and past. Earth-Science Reviews 163: 297-322.

Dimri AP, Yasunari T, Wiltshire A et al. (2013) Application of regional climate models to the Indian winter monsoon over the western Himalayas. Science of the Total Environment 468: S36-S47.

Donato SV, Reinhardt EG, Boyce JI et al. (2009) Particle-size distribution of inferred tsunami deposits in Sur Lagoon, Sultanate of Oman. Marine Geology 257: 54-64.

Doose-Rolinski H, Rogalla U, Scheeder G et al. (2001) High-resolution temperature and evaporation changes during the LateHolocene in the northeastern Arabian Sea. Paleoceanography 16: 358-367.

Field JP, Breshears DD and Whicker JJ (2009) Toward a more holistic perspective of soil erosion: Why aeolian research needs to explicitly consider fluvial processes and interactions. Aeolian Research 1(1-2): 9-17.

Findlater J (1977) Observational aspects of the low-level crossequatorial jet stream of the western Indian Ocean. Pure and Applied Geophysics 115(5-6): 1251-1262.

Fink C, Baumann K-H, Groeneveld J et al. (2010) Strontium/ Calcium ratio, carbon and oxygen stable isotopes in coccolith carbonate from different grain-size fractions in South Atlantic surface sediments. Geobios 43(1): 151-164.

Fischer D, Mogollón JM, Strasser M et al. (2013) Subduction zone earthquake as potential trigger of submarine hydrocarbon seepage. Nature Geoscience 6: 647-651.

Fletcher WJ, Debret M and Sanchez Goñi MF (2012) MidHolocene emergence of a low-frequency millennial oscillation in western Mediterranean climate: Implications for past dynamics of the North Atlantic atmospheric westerlies. The Holocene. Available at: http://hol.sagepub.com/con tent/early/2012/10/25/0959683612460783.abstract.

Gadgil S (2003) The Indian monsoon and its variability. Annual Review of Earth and Planetary Science 31: $429-467$.
Gaye B, Nagel B, Dähnke K et al. (2013) Evidence of parallel denitrification and nitrite oxidation in the ODZ of the Arabian Sea from paired stable isotopes of nitrate and nitrite. Global Biogeochemical Cycles 27(4): 1059-1071.

Goudie AS and Middleton NJ (2000) Dust storms in South West Asia. Geographica 35: 73-83.

Hampton MA, Lee HJ and Locat J (1996) Submarine landslides. Reviews of Geophysics 34(1): 33-59.

Hartmann H, Lange H, Seibold E et al. (1971) Oberflächensedimente im Persischen Golf und Golf von Oman. I. Geologisch-hydrologischer Rahmen und erste sedimentologische Ergebnisse "Meteor" Forschungsergebnisse, 4. Borntraeger: Reihe C. Wissenschaftsverlage Schweizerbart und Gebr, p. 76.

Hastenrath S (1996) Climate Dynamics of the Tropics. Kluwer Academic Publishers. Available at: http://books.google.de /books?id=3kbj46xFpnkC.

Heidarzadeh M, Pirooz MD, Zaker NH et al. (2008) Historical tsunami in the Makran Subduction Zone off the southern coasts of Iran and Pakistan and results of numerical modeling. Ocean Engineering 35: 774-786.

Heidarzadeh M, Pirooz MD, Zaker NH et al. (2009) Preliminary estimation of the tsunami hazards associated with the Makran subduction zone at the northwestern Indian Ocean. Natural Hazards 48: 229-243.

Herman JR, Bhartia PK, Torres O et al. (1997) Global distribution of UV-absorbing aerosols from Nimbus 7/TOMS data. Journal of Geophysical Research: Atmospheres 102(D14): 16911-16922.

Honjo S, Manganini SJ and Poppe LJ (1982) Sedimentation of lithogenic particles in the deep ocean. Marine Geology 50(3): 199-220.

IFRC (1999) Pakistan: Floods. Situation Report. Available at: http://www.ifrc.org/docs/appeals/98/089802f.pdf.

Ittekkot V (1993) The abiotically driven biological pump in the ocean and short-term fluctuations in atmospheric CO2 contents. Global and Planetary Change 8: 17-25.

Ittekkot V and Arain R (1986) Nature of particulate organic-matter in the River Indus, Pakistan. Geochimica Et Cosmochimica Acta 50: 1643-1653.

Ivory SJ and Lézine A-M (2009) Climate and environmental change at the end of the Holocene Humid Period: A pollen record off Pakistan. Histoire Climatique des déserts d'Afrique et d'Arabie [Climatic History of the African and Arabian Deserts] 341(8-9): 760-769.

Jayaraman KS (2002) Climate model under fire as rains fail India. Nature 418(6899): 713-713.

Kaskaoutis DG, Rashki A, Houssos EE et al. (2014) Extremely high aerosol loading over Arabian Sea during June 2008: The specific role of the atmospheric dynamics and Sistan dust storms. Atmospheric Environment 94: 374-384.

Kaskaoutis DG, Rashki A, Houssos EE et al. (2015) Meteorological aspects associated with dust storms in the Sistan region, southeastern Iran. Climate Dynamics 45(1): 407-424.

Katz T, Ginat H, Eyal G et al. (2015) Desert flash floods form hyperpycnal flows in the coral-rich Gulf of Aqaba, Red Sea. Earth and Planetary Science Letters 417: 87-98.

Knapp KR, Applequist S, Diamond HJ et al. (2010) NCDC International Best Track Archive for Climate Stewardship (IBTrACS) Project, version 3. NOAA National Climatic Data Center. Available at: http://dx.doi.org/10.7289/V5NK3BZP (accessed 25 March 2016).

Kolla V and Biscaye PE (1977) Distribution and origin of quartz in the sediments of the Indian Ocean. Journal of Sedimentary Research 47: 642-649.

Kolla V, Henderson L and Biscaye PE (1976) Clay mineralogy and sedimentation in the western Indian Ocean. Deep Sea Research and Oceanographic Abstracts 23: 949-961. 
Kolla V, Kostecki JA, Robinson F et al. (1981) Distributions and origins of clay minerals and quartz in surface sediments of the Arabian Sea. Journal of Sedimentary Research 51: 563-569.

Koster B, Hoffmann G, Grützner C et al. (2014) Ground penetrating radar facies of inferred tsunami deposits on the shores of the Arabian Sea (Northern Indian Ocean). Marine Geology 351: 13-24.

Lauterbach S, Witt R, Plessen B et al. (2014) Climatic imprint of the mid-latitude Westerlies in the Central Tian Shan of Kyrgyzstan and teleconnections to North Atlantic climate variability during the last 6000 years. The Holocene. Available at: http://hol.sagepub.com/content/early/2014/06/04/0959683 614534741.abstract.

Lückge A (1997) Ablagerung und Frühdiagenese organischen materials in marinen Hochproduktivitatsgebieten. Berichte Forschungszentrum Jülich 3413. Jülich: Institut für Chemie und Dynamik der Geosphäre 4: Erdöl und Organische Geochemie.

Lückge A, Deplazes G, Schulz H et al. (2012) Impact of Indus River discharge on productivity and preservation of organic carbon in the Arabian Sea over the twentieth century. Geology. Available at: http://geology.gsapubs.org/content/ early/2012/03/23/G32608.1.abstract.

Lückge A, Doose-Rolinski H, Khan AA et al. (2001) Monsoonal variability in the northeastern Arabian Sea during the past 5000 years: Geochemical evidence from laminated sediments. Palaeogeography, Palaeoclimatology, Palaeoecology 167: 273-286.

Lückge A, Reinhardt L, Andruleit H et al. (2002) Formation of varve-like laminae off Pakistan: Decoding 5 years of sedimentation. Geological Society, London, Special Publications 195: 421-431.

McCave IN (2017) Formation of sediment waves by turbidity currents and geostrophic flows: A discussion. Marine Geology 390: 89-93.

McCave IN and Hall IR (2006) Size sorting in marine muds: Processes, pitfalls, and prospects for paleoflow-speed proxies. Geochemistry Geophysics Geosystems 7: 37.

Mahowald N, Albani S, Kok JF et al. (2013) The size distribution of desert dust aerosols and its impact on the Earth system. Aeolian Research. Available at: http://www.sciencedirect. com/science/article/pii/S1875963713000736.

Mahowald N, Ward DS, Kloster S et al. (2011) Aerosol impacts on climate and biogeochemistry. Annual Review of Environment and Resources 36(1): 45-74.

Mahowald NM, Baker AR, Bergametti G et al. (2005) Atmospheric global dust cycle and iron inputs to the ocean. Global Biogeochemical Cycles 19(4): GB4025.

MAKRAN II Cruise Report (1998) Makran II: The Makran Accretionary Wedge Off Pakistan - Tectonic Evolution and Fluid Migration (Part 2). Cruise Report SO-130. Hannover: Bundesanstalt für Geowissenschaften und Rohstoffe.

Meyers PA (1997) Organic geochemical proxies of paleoceanographic, paleolimnologic, and paleoclimatic processes. Organic Geochemistry 27(5-6): 213-250.

Middleton NJ (1986) A geography of dust storms in South-West Asia. Journal of Climatology 6: 183-196.

Milliman JD and Farnsworth KL (2011) River Discharge to the Coastal Ocean: A Global Synthesis. Cambridge: Cambridge University Press. Available at: http://site.ebrary.com/lib/suub/ docDetail.action?docID=10455723.

Müller P (1977) CN ratios in Pacific deep-sea sediments: Effect of inorganic ammonium and organic nitrogen compounds sorbed by clays. Geochimica et Cosmochimica Acta 41(6): 765-776.

Munz PM, Siccha M, Luckge A et al. (2015) Decadal-resolution record of winter monsoon intensity over the last two millennia from planktic foraminiferal assemblages in the northeastern Arabian Sea. The Holocene 25: 1756-1771.

Osterberg C, Small L and Hubbard L (1963) Radioactivity in large marine plankton as a function of surface area. Nature 197(4870): 883-884.

Page WD, Alt JN, Cluff LS et al. (1979) Evidence for the recurrence of large-magnitude earthquakes along the Makran coast of Iran and Pakistan. Tectonophysics 52(1-4): 533-547.

Petschick R, Kuhn G and Gingele F (1996) Clay mineral distribution in surface sediments of the South Atlantic: Sources, transport, and relation to oceanography. Marine Geology 130: 203-229.

Prasad S and Enzel Y (2006) Holocene paleoclimates of India. Holocene Climate and Cultural Evolution in Late Prehistoric-Early Historic West Asia 66: 442-453.

Prasad S, Anoop A, Riedel N et al. (2014) Prolonged monsoon droughts and links to Indo-Pacific warm pool: A Holocene record from Lonar Lake, Central India. Earth and Planetary Science Letters 391: 171-182.

Prins MA Weltje GJ (1999) End-member modeling of siliciclastic grain-size distributions: The late Quaternary record of aeolian and fluvial sediment supply to the Arabian Sea and its paleoclimatic significance. In: Harbaugh J (ed.) Numerical Experiments in Stratigraphy: Recent Advances in Stratigraphicl Sedimentologic Computer Simulations. SEPM Special Publication, no. 61. Broken Arrow, OK: Society for Sedimentary Geology, pp. 91-111.

Prins MA, Postma G and Weltje GJ (2000) Controls on terrigenous sediment supply to the Arabian Sea during the late Quaternary: The Makran continental slope. Marine Geology 169: 351-371.

Prospero JM, Ginoux P, Torres O et al. (2002) Environmental characterization of global sources of atmospheric soil dust identified with the NIMBUS 7 Total Ozone Mapping Spectrometer (TOMS) absorbing aerosol product. Reviews of Geophysics 40: 1002.

PyeK(1987)AeolianDustandDustDeposits. Academic Press.Available at: http://books.google.de/books?id=FF8RAQAAIAAJ.

Quade J, Rech JA, Latorre C et al. (2007) Soils at the hyperarid margin: The isotopic composition of soil carbonate from the Atacama Desert, Northern Chile. Geochimica et Cosmochimica Acta 71(15): 3772-3795.

Rajeev S, Rajiv N, Andreas M et al. (2012) Linkage between seasonal insolation gradient in the tropical northern hemisphere and the sea surface salinity of the equatorial Indian Ocean during the last glacial period. Acta Geologica Sinica-English Edition 86: 1265-1275.

Ramage CS (1987) Monsoon climates. In: Climatology, Encyclopedia of Earth Science. Springer, pp. 590-593. Available at: http://dx.doi.org/10.1007/0-387-30749-4_118.

Ramaswamy V and Gaye B (2006) Regional variations in the fluxes of foraminifera carbonate, coccolithophorid carbonate and biogenic opal in the northern Indian Ocean. Deep Sea Research Part I: Oceanographic Research Papers 53: 271-293.

Rashki A, Kaskaoutis DG, Francois P et al. (2015) Dust-storm dynamics over Sistan region, Iran: Seasonality, transport characteristics and affected areas. Aeolian Research 16: $35-48$.

Rashki A, Kaskaoutis DG, Goudie AS et al. (2013) Dryness of ephemeral lakes and consequences for dust activity: The case of the Hamoun drainage basin, Southeastern Iran. Science of the Total Environment 463-464: 552-564.

Rastogi BK and Jaiswal RK (2006) A catalog of tsunamis in the Indian Ocean. Science of Tsunami Hazards 25: 128-143.

Reichart GJ, den Dulk M, Visser HJ et al. (1997) A 225 kyr record of dust supply, paleoproductivity and the oxygen minimum 
zone from the Murray Ridge (northern Arabian Sea). Palaeogeography, Palaeoclimatology, Palaeoecology 134: 149-169.

Reid I and Laronne JB (1995) Bed load sediment transport in an ephemeral stream and a comparison with seasonal and perennial counterparts. Water Resources Research 31(3): 773-781.

Rezazadeh M, Irannejad P and Shao Y (2013) Climatology of the Middle East dust events. Aeolian Research 10: 103-109.

Rixen T and Ittekkot V (2005) Nitrogen deficits in the Arabian Sea, implications from a three component mixing analysis. Deep Sea Research Part II: Topical Studies in Oceanography 52(14-15): 1879-1891.

Rixen T, Haake B and Ittekkot V (2000) Sedimentation in the western Arabian Sea: The role of coastal and open-ocean upwelling. In: Ganssen G and Wefer G (eds) Deep-Sea Research, Part 2: Topical Studies in Oceanography. Elsevier, pp. 2155-2178. Available at: http://www.refdoc.fr/Detailnoti ce?idarticle $=10813066$.

Rixen T, Baum A, Gaye B et al. (2014) Seasonal and interannual variations in the nitrogen cycle in the Arabian Sea. Biogeosciences 11(20): 5733-5747.

Rixen T, Haake B, Ittekkot V et al. (1996) Coupling between SW monsoon related surface and deep Ocean processes as discerned from continuous particle flux measurements and correlated satellite data. Journal of Geophysical Research 101: 28569-28582.

Rixen T, Ramaswamy V, Gaye B et al. (2009) Monsoonal and ENSO impacts on export fluxes and the biological pump in the Indian Ocean. In: Hood RR, Wiggert JD, Naqvi SWA et al. (eds) Indian Ocean Biogeochemical Processes and Ecological Variability. Washington, DC: AGU, pp. 365-383.

Roberts N and Wright HE (1993) Vegetational, lake-Level, and climatic history of the Near East and Southwest Asia. In: Wright HE (ed.) Global Climates since the Last Glacial Maximum. Minneapolis, MN: University of Minnesota Press, pp. 194-220.

Rostek F, Bard E, Beaufort L et al. (1997) Sea surface temperature and productivity records for the past $240 \mathrm{kyr}$ in the Arabian Sea. Deep Sea Research Part II: Topical Studies in Oceanography 44: 1461-1480.

Schiebel R, Zeltner A, Treppke UF et al. (2004) Distribution of diatoms, coccolithophores and planktic foraminifers along a trophic gradient during SW monsoon in the Arabian Sea. Marine Micropaleontology 51(3-4): 345-371.

Schlesinger WH, Marion GM and Fonteyn PJ (1989) Stable isotope ratios and the dynamics of caliche in desert soils. In: Rundel PW, Ehleringer JR and Nagy KA (eds) Stable Isotopes in Ecological Research, Ecological Studies. New York: Springer, pp. 309-317. Available at: http://dx.doi. org/10.1007/978-1-4612-3498-2_18.

Schlitzer R (2000) Applying the adjoint method for biogeochemical modeling: Export of particulate organic matter in the World Ocean. In: Kasibhata P, Heimann M, Rayner P et al. (eds) Inverse Methods in Biogeochemical Cycles. Washington, DC: American Geophysical Union (AGU Monograph 114), pp. 107-124.

Scholten JC, Fietzke J, Mangini A et al. (2005) Radionuclide fluxes in the Arabian Sea: The role of particle composition. Earth and Planetary Science Letters 230(3-4): 319-337.

Schulz H and Von Rad U (2014) Vertical and lateral flux on the continental slope off Pakistan: Correlation of sediment core and trap results. Biogeosciences 11(12): 3107-3120.

Schulz H, Rad U and Erlenkeuser H (1998) Correlation between Arabian Sea and Greenland climate oscillations of the past 110,000 years. Nature 393: 54-57.

Schulz H, Rad U and Stackelberg U (1996) Laminated sediments from the oxygen-minimum zone of the northeastern Arabian Sea. Geological Society, London, Special Publications 116: 185-207.
Schulz H, von Rad U and Ittekkot V (2002) Planktic foraminifera, particle flux and oceanic productivity off Pakistan, NE Arabian Sea: Modern analogues and application to the palaeoclimatic record. Geological Society, London, Special Publications 195: 499-516.

Seinfeld JH and Pandis SN (2006) Atmospheric Chemistry and Physics: From Air Pollution to Climate Change. 2nd Edition. Hoboken, NJ: John Wiley.

Sen Gupta R, Rajagopal MD and Qasim SZ (1976) Relationship between dissolved oxygen and nutrients in the northwestern Indian Ocean. Indian Journal of Marine Sciences 5: 201-211.

Silver MW and Alldredge AL (1981) Bathypelagic marine snow: Deep-sea algal and detrital community. Journal of Marine Research 39: 501-530.

Sirocko F and Lange H (1991) Clay-mineral accumulation rates in the Arabian Sea during the late Quaternary. Marine Geology 97: 105-119.

Sirocko F and Sarnthein M (1989) Wind-borne deposits in the northwestern Indian Ocean: Record of Holocene sediments versus modern satellite data. In: Leinen $M$ and Sarnthein M (eds) Paleoclimatology and Paleometeorology: Modern and Past Patterns of Glacial Atmospheric Transport (NATO ASI Series). Dordrecht: Kluwer Academic, pp. 401-433.

Sirocko F, Sarnthein M, Lange H et al. (1991) Atmospheric summer circulation and coastal upwelling in the Arabian Sea during the Holocene and the last glaciation. Quaternary Research 36: 72-93.

Snead RE (1966) Physical Geography Reconnaissance: Las Bela Coastal Plain, West Pakistan. Baton Rouge, LA: Louisiana State University Press.

Snead RE (1968) Weather patterns in Southern West Pakistan. Archiv für Meteorologie, Geophysik und Bioklimatologie, Serie B 16: 316-346.

Staubwasser M and Sirocko F (2001) On the formation of laminated sediments on the continental margin off Pakistan: The effects of sediment provenance and sediment redistribution. Marine Geology 172: 43-56.

Staubwasser M, Sirocko F, Grootes PM et al. (2003) Climate change at the $4.2 \mathrm{ka}$ BP termination of the Indus valley civilization and Holocene south Asian monsoon variability. Geophysical Research Letters 30: 1425.

Stewart RA, Pilkey OH and Nelson BW (1965) Sediments of the northern Arabian Sea. Marine Geology 3: 411-427.

Stiller M, Rounick JS and Shasha S (1985) Extreme carbon-isotope enrichments in evaporating brines. Nature 316(6027): 434-435.

Sun D, Bloemendal J, Rea DK et al. (2002) Grain-size distribution function of polymodal sediments in hydraulic and aeolian environments, and numerical partitioning of the sedimentary components. Sedimentary Geology 152: 263-277.

Suzuki N and Kato K (1953) Studies on suspended materials marine snow in the sea: part 1. Source of marine snow. Bulletin of the Faculty of Fisheries, Hokkaido University 4: 132-135.

Syed FS, Giorgi F, Pal JS et al. (2006) Effect of remote forcings on the winter precipitation of central Southwest Asia part 1: observations. Theoretical and Applied Climatology 86(1-4): 147-160.

Syed FS, Giorgi F, Pal JS et al. (2010) Regional climate model simulation of winter climate over Central-Southwest Asia, with emphasis on NAO and ENSO effects. International Journal of Climatology 30(2): 220-235.

Tiemann J (2001) Korngrößen und mineralogische Zusammensetzung von Sinkstoffen und Oberflächensedimenten aus dem Arabischen Meer - Hinweise auf Quellen und Transport des 
lithogenen Materials. Dissertation. Hamburg: Department of Geosciences, University of Hamburg, $120 \mathrm{pp}$.

Usbeck R, Schlitzer R, Fischer G et al. (2003) Particle fluxes in the ocean: Comparison of sediment trap data with results from inverse modeling. Journal of Marine Systems 39(3-4): $167-183$

Vogt C, Lauterjung J and Fischer RX (2002) Investigation of the clay fraction $(<2 \mu \mathrm{m})$ of the clay minerals society reference clays. Clays and Clay Minerals 50: 388-400.

Von Rad U and Tahir M (1997) Late Quaternary sedimentation on the outer Indus shelf and slope (Pakistan): Evidence from high-resolution seismic data and coring. Marine Geology 138: 193-196.

Von Rad U, Delisle G and Lückge A (2002a) On the formation of laminated sediments on the continental margin off Pakistan. Marine Geology 192: 425-429.

Von Rad U, Khan AA, Berger WH et al. (2002b) Varves, turbidites and cycles in upper Holocene sediments (Makran slope, northern Arabian Sea). Geological Society, London, Special Publications 195: 387-406.

Von Rad U, Rösch H, Berner U et al. (1996) Authigenic carbonates derived from oxidized methane vented from the Makran accretionary prism off Pakistan. Marine Geology 136(1-2): $55-77$.

Von Rad U, Schaaf M, Michels KH et al. (1999a) A 5000-yr record of climate change in varved sediments from the oxygen minimum zone off Pakistan, northeastern Arabian Sea. Quaternary Research 51: 39-53.

Von Rad U, Schulz H, Riech V et al. (1999b) Multiple monsooncontrolled breakdown of oxygen-minimum conditions during the past 30,000 years documented in laminated sediments off Pakistan. Palaeogeography, Palaeoclimatology, Palaeoecology 152: 129-161.

Waelbroeck C, Levi C, Duplessy JC et al. (2006) Distant origin of circulation changes in the Indian Ocean during the last deglaciation. Earth and Planetary Science Letters 243: 244-251.

Weyhenmeyer CE, Burns SJ, Waber HN et al. (2000) Cool glacial temperatures and changes in moisture source recorded in Oman groundwaters. Science 287: 842-845.

Whitney JW (2006) Geology, Water, and Wind in the Lower Helmand Basin, Southern Afghanistan. Scientific Investigation Report 2006-5182. Denver, CO: US Geological Survey Information Services.

Wilhelms-Dick D, Westerhold T, Röhl U et al. (2012) A comparison of mm scale resolution techniques for element analysis in sediment cores. Journal of Analytical Atomic Spectrometry 27: $1574-1584$.

Yadav RK, Ramu DA and Dimri AP (2013) On the relationship between ENSO patterns and winter precipitation over North and Central India. Global and Planetary Change 107: $50-58$.

Yu E-F, Francois R, Bacon M et al. (2001) Trapping efficiency of bottom-tethered sediment traps estimated from the intercepted fluxes of 230Th and 231Pa. Deep Sea Research Part I: Oceanographic Research Papers 48(3): 865-889.

Zhao Y, Wu F, Fang X et al. (2015) Topsoil C/N ratios in the Qilian Mountains area: Implications for the use of subaqueous sediment $\mathrm{C} / \mathrm{N}$ ratios in paleo-environmental reconstructions to indicate organic sources. Palaeogeography, Palaeoclimatology, Palaeoecology 426: 1-9. 